\title{
Ortak Bilgi Yapılandırma Modeline Göre Yapılan Öğretimin Altıncı Sınıf Öğrencilerinin Işık Konusuna İlişkin Kavramsal Anlamalarına Etkisi ${ }^{1}$
}

DOI: 10.26466/opus.751220

\author{
$*$ \\ Huriye Ylldıbaš ${ }^{*}$ - Hatice Güzel ** \\ * Öğretmen Milli Eğitim Bakanlığı, Karaman/ TÜRKIYYE \\ E-Posta: hsybs@hotmail.com \\ ORCID: 0000-0001-5568-0398 \\ ** Prof. Dr. Karamanoğlu Mehmetbey Üniversitesi, Eğitim Fakültesi, Matematik ve Fen Bilimleri \\ Eğitimi Bölümü, Karaman \\ E-Posta: $\underline{\text { haticeguzel@kmu.edu.tr }}$ \\ ORCID: $\underline{0000-0000-5678-4447}$
}

$\ddot{O} z$

Bu Araştırmanın amacı, ortaokul 6. Sinıf Fen Bilimleri dersinde "Işık ve Ses" ünitesine ait "Işı̆̆ın Yansıması" konusunun öğretilmesinde Ortak Bilgi Yapılandırma Modeli (OBYM)'ye göre yürütülen öğretimin öğrencilerin kavramsal anlamalarına etkisini incelemektir. Araştırmanın çalışma grubunu 2014-2015 Eğitim Öğretim yılında Karaman il merkezinde yer alan Alparslan Ortaokulundaki 6. Sını öğrencilerinden 31 kontrol grubu, 33 deney grubu olmak üzere toplam 64 öğrenci oluşturmaktadır. Araştırmada veri toplama aracı olarak; Işık Konusu Kavramsal Anlama Testi (IKKAT) kullanılmıştır Araştırmada karma yöntem kullanılmıştır. Araştırmadan elde edilen veriler, SPSS programı kullanılarak analiz edilmiştir. Araştırmada elde edilen nicel verilerin değerlendirilmesinde; bağımsız ttesti, nitel verilerin değerlendirilmesinde ise içerik analizi ve betimsel analiz kullanılmıştır. Araştırmada OBYM ile 5E öğretim modelinin kavramsal anlamaya etkisi karşılaştırılmıştır. Dersler deney grubunda OBYM'ye, kontrol grubunda $5 E$ öğretim modeline göre işlenmiştir Konularm OBYM'ne göre işlendiği deney grubu öğrencilerinin IKKAT ön-test ve son-test puan ortalamaları arasında son test lehine anlamlı bir farklılık olduğu bulunmuştur. OBYM'nin 6. Sinnf öğrencilerinin kavramsal anlamaların artırdığı görülmüştür.

Anahtar Kelimeler: Ortak Bilgi Yapılandırma Modeli, Işık Konusu, Kavramsal Anlama, fen Öğretimi

\footnotetext{
${ }^{1}$ Bu çalışma birinci yazarın yüksek lisans tezinden türetilmiştir
} 


\title{
The Effect of Teaching Based on the Common Knowledge Construction Model on the Conceptual Understanding of Sixth Grade Students Regarding the Subject of Light
}

\begin{abstract}
The aim of this study is to examine the effect of teaching conducted according to the Common Knowledge Construction Model (CKCM) in teaching the subject of "Reflection of Light" from the "Light and Sound" unit in the Science course of the 6th Grade in secondary school. The study group of the study consisted of 64 students, including 31 in the control group and 33 in the experimental group in Alparslan Secondary School located in the city centre of Karaman province in the 2014-2015 academic year. The Light Subject Conceptual Understanding Test (LSCUT) was used as a data collection tool in the research. The mixed method was used in the research. The data obtained from the research were analyzed by using the SPSS program. Independent $t$-test was used in the evaluation of the quantitative data obtained in the research, and content analysis and descriptive analysis were used in the evaluation of the qualitative data. In the study, the effect of CKCM and 5E teaching model on conceptual understanding was compared. The lessons were taught according to CKCM in the experimental group and 5E teaching model in the control group. It was found that there was a significant difference between the LSCUT pre-test and post-test mean scores of the students in the experimental group, in which subjects were taught according to CKCM. It is seen that the CKCM increased the conceptual understanding of 6 th grade students
\end{abstract}

Keywords: Common Information Construction Model, Light Subject, Conceptual Understanding, Science Teaching 


\section{Giriş}

İçinde bulunduğumuz bilgi çağında bilim ve teknolojinin gelişimi, nitelikli insan gücüne olan gereksinimi giderek arttırmaktadır. Bireylere bu nitelikler kazandırılmalı, çağın getirebileceği yeniliklere uyum sağlayabilmeleri amacıyla temel kavramları özümsetmeyi amaçlayan çağdaş eğitim verilmelidir (Öztunç, 1999). Ülkemiz diğer gelişmiş ülkelerde olduğu gibi, okullarda fen bilimleri eğitimini daha etkili hale getirmek için yeni arayışlar içerisine girmiş bu amaçla, fen bilimleri dersi öğretim programlarında değişikliğe gitmiştir. Bu noktadan hareketle, ülkemizde fen bilimleri öğretim programları birçok defa güncellemiş veya değiştirilmiştir.

2018 Fen Bilimleri Dersi Öğretim Programi'nda öğrenme-öğretme kuram ve uygulamaları açısından bütüncül bir bakış açısı benimsenmiş; genel olarak öğrencinin kendi öğrenmesinden sorumlu olduğu, öğrenme sürecine aktif katılımının sağlandığı, araştırma-sorgulama ve bilginin transferine dayalı öğrenme stratejisi esas alınmıştır öğrencinin bilginin kaynağını araştıran, sorgulayan, açıklayan, tartş̧an ve ürüne dönüştüren birey rolünü üstlenmesi istenmiştir. ( Milli Eğitim Bakanlı̆̆g, 2018)

Günlük yaşantımızda oldukça fazla öneme sahip olan fen bilimleri ile ilgili kavramların anlaşılır olması, öğrencilerin bilgiyi oluşturmasında ve kalıcı öğrenmelerinin gerçekleşmesinde oldukça önemlidir. Sınırlı konu alanı bilgisi öğrencilerin kavramsal anlamalarını zorlaştırmaktadır. Öğrencilerde herhangi bir konu ile ilgili kavramsal anlamanın sağlanması eğitimin en temel amaçları arasındadır ( Çalik ve diğer, 2007).

Kavramsal anlama kavram geliştirme süreci olup; bilgilerin açıklanması, yorumlanması, örneklendirilmesi ve sinıflandırılmasıdır. Kavramsal anlama; öğrencilerin yeni kavramı, daha önceden öğrenmiş oldukları kavramla açılayarak ve ilişkilendirerek kendi cümleleri ile ifade etmesi şeklinde de tanımlanabilir. Sinan (2007), kavramsal anlamay1, kavramlar arasında benzerlik ve farklılıkları bulabilme, kavramları birbiri ile ilişkilendirebilme ve başka durumlara aktarabilme, problemlerin çözümünde kullanabilme olarak tarif etmiştir. Ayrıca kavramsal anlamanın derin bir öğrenme olduğunu belirtmiştir.

Fen bilimleri dersinde pek çok soyut kavram vardır. Bu durum öğrencilerin zihinlerinde alternatif kavramlar oluşturmalarına sebep olmaktadır. Birçok araştırmada, öğrenciler hangi sınıf seviyesi olursa olsun soyut konu- 
ların öğretilmesinin zor olduğu (Ayas ve Demirbaş, 1997; Cerit Berber, ve Sarı, 2009; Reid, 2008; Orgill ve Bodner, 2004) ve öğrencilerin soyut özellik taşıyan konularda çeşitli alternatif kavramlar taşıdıkları ifade edilmektedir (Cerit Berber ve Sar1, 2010; Karslı ve Ayas, 2013; Mutlu ve Acar Şeşen, 2016). Fen bilimleri dersinde kavramsal anlamanın gerçekleşmesi, soyut kavramların somutlaştırılması, görsel materyallerin kullanılması ve farklı tekniklere yer verilmesi ile sağlanabilir (Gobert ve Clement, 1999). Kavramsal değişim, öğrencilerin bilimsel olmayan ancak zihinlerinde yerleşmiş inanç yapısını oluşturan temel kavramlarında bilimsel olarak doğru kabul edilen bilgilere doğru köklü değişiklikler yapılması sürecidir (Anderson, 2007). Kavramsal değişim; öğrencilerin ön bilgileri üzerine yeni bilgi eklenmesi sırasında bilimsel olarak kabul görmeyen ön kavramlarının değişimi olarak da tanımlanabilir.

Kavramsal değişimin sağlanmasında öğretim yöntemlerinden yapılandırmacı ığrenme kuramını yararlı olduğu. kuramın yanlış ya da eksik kavramsal anlamalara sahip olan öğrencilerin kavramlarını bilimsel olanlarla değiştirmelerinde etkili olduğu görülmüştür (Kayalı ve Tarhan, 2004).

Yapılandırmacı öğrenme kuramının temelinde öğrencilerin yaparak ve yaşayarak var olan ön bilgilerinin üzerine doğrularının inşa edilmesi yatar. Bu süreçte kavramsal değişim stratejileri ön plana çıkmaktadır (HyslopMargison ve Strobel, 2007; Treagust ve Duit, 2008). Kavramsal değişimin sağlanmasında kavramsal değişim metinleri, kavram haritaları, analojiler, animasyonlar, çalışma yaprakları gibi teknikler kullanılabilmektedir.

Öğrencilerin kavramsal anlamalarının iyileştirilmesinde etkili olan öğretim modellerinden bir diğeri de yapılandırmac öğrenme kuramına uygun olarak geliştirilen Ortak Bilgi Yapılandırma Modeli (OBYM)'dir. Ortak Bilgi Yapılandırma Modeli (OBYM) Ebenezer ve Connor tarafindan 1998 yılında geliştirilmiştir. OBYM; Keşfetme ve Sınıflandırma, Yapılandırma ve Müzakere Etme, Genişletme ve Transfer Etme, Yansitma ve Değerlendirme olmak üzere dört aşamadan oluşmaktadır. Keşfetme ve sinıflandırma aşamasında öğrencilerin konuyla ilgili alternatif kavramları tespit edilir. Yapılandırma ve müzakere etme aşamasında öğrenciler, kavramsal değişim sürecinin; araştırma, eleştirel düşünme, müzakere, paylaşım gibi süreçlerin sonunda zihinde oluşan anlamlar sayesinde gerçekleştiğinin farkına varır (Ebenezer, \& Connor, 1998). 
Modelin Genişletme ve müzakere etme aşamasında öğrenciler konuyla ilgili öğrendikleri bilgileri diğer kavramlarla ilişkilendirerek yeni durumlara uygularlar. OBYM'nin dördüncü aşamasındaı, öğrencilerin deneyimlerinden yola çkarak var olan kavramlarının keşfedilmesi ve kategorize edilmesi ve aynı zamanda kavramsal anlama için etkili öğrenmenin nasıl olması gerektiği belirlenmeye çalışılır. OBYM'nin ikinci ve üçüncü aşamalarında gerçekleştirilen etkinlikler sonucunda öğrencilerin eleştirel düşünme becerilerinin geliştiği, OBYM'nin akademik başarı ve kavramsal değişim üzerinde etkili bir öğretim modeli olduğu görülmüştür. Ebenezer, Chacko, Kaya, Koya, Ebenezer'e (2010) göre, kavramsal değişim sürecinde izlenmesi gereken adımlar: öğrencilerin kavramlarının keşfedilmesi, öğrencilerin kendi kavramlarından haberdar edilmesi, öğrencilerin öğrenme ortamında kendi kişisel kavramlarını paylaşmaları, öğrencilerin kendi kavramları ile bilimsel model veya açıklamaları karşılaştırmaları, sosyal bir öğrenme ortamı içinde öğrencinin ön kavramlarının düzeltmesi, uzlaştırması, yeniden düzenlemesi veya kendi ön kavramın terk ederek bilimsel olanı kabul etmesi sağlanmalı şeklindedir. Özet olarak, öğrencilerin alternatif kavramlarının giderilmesi amacıyla modelin birinci aşamasında bütün öğrencilerin konu hakkında düşünceleri belirlenmeye çalışılır. Bu aşamada ortaya çıkan alternatif kavramlar ikinci aşamada tartışılır, üçüncü aşamada ise yapılandırılır. İkinci aşamada, her öğrencinin kendi fikrini tartışarak ve düşünerek ifade etmesine firsat verilmelidir. Özellikle üçüncü aşamada farklı stratejiler kullanılarak (örneğin; kavramsal değişim metinleri ve kavram karikatürleri vb.) birinci aşamada ortaya çıkan alternatif kavramların giderilmesine çalışılır (Bakırc1, 2014).

OBYM ile ilgili yapılan çalışmalar incelendiğinde; Ebenezer, Chacko ve Immanual'in (2004), OBYM esaslı yürütülen bir derste, öğretmen görüşlerine dayalı olarak dersin etkililiğinin belirlenmesine; Biemacka'nın (2006), ilköğretim 5. sınıf öğrencilerinin hava olayları ünitesi kapsamında bilimsel okuryazarlıklarının gelişmesinde OBYM'nin etkisinin belirlenmesine; Ebenezer vd. nin(2010), OBYM ile 7. sınıf öğrencilerinin boşaltım sistemi konusuyla ilgili alternatif kavramlarının giderilmesine; Wood'un (2012), OBYM ile lise öğrencilerinin asit- bazlarla ilgili kavramsal değişimlerine ve fen başarılarına etkisine; İyibil (2011)'in, OBYM ile 7. sınıf öğrencilerine enerji kavramının öğretilmesine; Vural, Demircioğlu ve Demircioğlu'nun (2012), asitbazlar konusunun öğretiminde OBYM'ye göre materyallerin geliştirilmesi, 
uygulanması ve değerlendirilmesine; Çepni, Özmen ve Bakırcı'nın (2012), OBYM'ye göre 6. sınıf "Işığın Madde İle Etkileşimi ve Yansıma" konusuna uygun materyallerin geliştirilmesine; Bakırcı ve Çepni' nin (2012), OBYM'nin 5E öğretim modeli ile benzerlik ve faklılıklarının karşılaştırılmasına, Kıryak'ın (2013), OBYM'nin 7. sını öğrencilerinin su kirliliği konusundaki kavramsal anlamalarına etkisine ve Bakırcı ve Çepni'nin (2013), Fen Bilimleri Dersi Öğretim Programı temelinde OBYM'nin irdelenmesine; Bakırcı'nın (2014), OBYM'ye dayalı öğretim materyali tasarlama, uygulama ve modelin etkililiğini değerlendirmesine; yönelik çalışmalara ulaşılmıştır.

OBYM ile ilgili yapılan araştırma sonuçları incelendiğinde; modelin alternatif kavramların belirlenmesinde ve alternatif kavramların bilimsel kavramlarla değiştirilmesinde (kavramsal değişimde) etkili olduğu (İyibil, 2011; Kiryak; 2013; Wood, 2012), modelin kavramsal anlamayı sağladığı (Bakırcı ve Çepni, 2014; Bakırcı, Artun ve Şenel , 2016; Bakırcı ve Ensari 2018; Biernacka, 2006; Caymaz ve Aydın, 2019; Güzel ve Yıldızbaş,2017; Uzunkaya ve Güzel, 2019 ; Kiryak, 2013 ; Yıldızbaş,2017; Wood, 2012 ) görülmüştür.

OBYM'nin öğrencilerin kavramsal anlamalarını destekleyecek niteliklere sahip olduğu ve bu modele uygun olarak geliştirilen materyallerle farklı metotları bir arada kullanarak yapılan öğretimin alternatif kavramların giderilmesinde de etkili olduğu görüldüğünden OBYM'nin fen öğretiminde uygulamaya değer bir model olduğu söylenebilir (Bakırc1, 2014).

$\mathrm{Bu}$ doğrultuda ortaokul 6. Sınıf öğrencilerinin fen bilimleri dersi ışık konusunda kavramsal anlama düzeylerinin belirlenmesi önem arzetmektedir.

Araştırmanın amacl, ortaokul 6. Sınıf fen bilimleri dersinde yer alan "Işık ve Ses" ünitesine ait "Işık" konusunun öğretilmesinde OBYM' ye göre öğretimin öğrencilerin kavramsal anlamalarına etkisini araştırmaktır.

\section{Yöntem}

Bu bölümde, araştırmanın modeline, çalışma grubuna, veri toplama aracına, araştırmada kullanılan materyallere, veri toplama sürecine ve verilerin analizine ilişkin bilgilere yer verilmiştir

\section{Araştırmanın Modeli}

Bu araştırmada nicel ve nitel araştırma yöntemlerinin bir arada kullanıldığ karma yöntem kullanılmıştır. Karma yöntem, araştırma sürecinde nitel ve 
nicel yöntemlerin birlikte kullanımını kapsayan bir yaklaşımdır (Çepni, 2011). Bu yöntemle araştırma sonunda nicel verilere ulaşılırken nitel olarak da niçin bu sonuçlara ulaşıldığı açıklanabilmektedir. Birbirini destekleyen nicel ve nitel yöntemlerin bir arada kullanılması araştırma problemiyle ilgili daha kapsamlı yorumlamaların yapılmasına imkân verir (Creswell ve Plano-Clark 2007) Nicel veriler için deneysel araştırma desenlerinden ön test, son est kontrol gruplu yarı deneysel desen kullanılmıştır.

\section{Çalışma Grubu}

Araştırmanın çalışma grubunu 2014-2015 Eğitim Öğretim yılında Karaman il Merkezinde yer alan Alparslan Ortaokulundaki 6. Sınıf öğrencilerinden 31 kontrol grubu, 33 deney grubu olmak üzere toplam 64 öğrenci oluşturmaktadır. Okulda bulunan dört adet 6. Sınıf şubesine ön test uygulanmıştır. Yapılan ön test sonuçlarına göre 6/A ve 6/D sinıflarının akademik başarılarının birbirine yakın olduğu tespit edilmiştir. Rastgele bir seçimle 6/A sınıfı deney grubu ve 6/D sinıfı ise kontrol grubu olarak belirlenmiştir.

\section{Tablo 1. Örneklem grubunun sinıf ve cinsiyete göre dă̆ılımı}

\begin{tabular}{llll}
\hline Grup & Kiz & Erkek & Toplam \\
\hline Deney (6/A) & 17 & 16 & 33 \\
\hline Kontrol (6/D) & 13 & 18 & 31 \\
\hline Toplam & 30 & 34 & 64 \\
\hline
\end{tabular}

\section{Veri Toplama Araci}

OBYM nin kavramsal değişim üzerindeki etkisini belirlemek için ' Işık Konusu' Kavramsal Anlama Testi (IKKAT)” kullanılmıştır. Bunun için Işık ve Ses ünitesi ile ilgili Bakırcı (2014) tarafından geliştirilen veri toplama aracından yararlanılmıştır Araştırmanın nicel verilerini elde etmek için Işık Konusu Kavramsal Anlama Testi (IKKAT) kullanılmıştır. IKKAT birinci ve ikinci kısım olacak şekilde hazırlanmıştır. IKKAT'ın birinci kısmı doğru cevapla beraber 3 çeldirici içeren çoktan seçmeli, ikinci kısmı ise; birinci kısımda verilen cevabın nedenini içeren açık uçlu kısım olacak şekilde düzenlenmiştir Geliştirilen açık uçlu sorular aracılığıyla öğrencilerin, kavramları bilme, ayırt edebilme ve yerinde kullanma becerilerinin ölçülmesi hedeflenmiştir Nitel veriler için bu açık uçlu sorulara verilen cevaplardan yararlanılmıştır. 
Işık konusu deney grubuna OBYM ile kontrol grubuna ise 5E modeli ile verilmiştir.

\section{Işık Konusu Kavramsal Anlama Testinden Elde Edilen Verilerin Analizi}

İki aşamalı 4 sorudan oluşan IKKAT'ın birinci kısmı; doğru cevapla beraber 3 çeldirici içeren çoktan seçmeli, ikinci kısmı ise; birinci kısımda verilen cevabın nedenini içeren açık uçlu kısım olacak şekildedir. Ortaokul 6. sınıf öğrencilerinin IKKAT'ın açık uçlu kısmına verdikleri cevaplardan elde edilen verilerin analizinde Abraham, Grzybowski, Renner, ve Marek (1992) tarafından yürütülen bir çalışmadan faydalanılmıştır. Bu çalışmada anlamama (0 puan), özel alternatif kavram (1 puan), özel alternatif kavram ve kısmi anlama (2 puan), kısmi anlama (3 puan) ve tam anlama kategorileri (4 puan) olarak ifade edilmiştir. IKKAT'ın açık uçlu kısmına verilen cevapları analiz etmede kullanılan düzeyler ve düzeylere ait açıklayıcı tanımlar Tablo 2 'de verilmiştir.

Tablo 2. IKKAT'ın Açık Uçlu Kısmına Verilen Cevapları Analiz Etmede Kullanılan Düzeyler ve Bu Düzeylere Ait Açıklayıcı Tanımlar

\begin{tabular}{ll}
\hline Anlama Düzeyi & Düzeye Ait Açıklayıcı Tanım \\
\hline Tam Anlama (TA) & Geçerliliği olan cevabın tüm yönlerini içeren cevaplar. \\
\hline Kısmi Anlama (KA) & $\begin{array}{l}\text { Geçerli olan cevabın en az bir bileşeniniiçeren fakat tüm bileşenlerini } \\
\text { içermeyen cevaplar. }\end{array}$ \\
\hline $\begin{array}{l}\text { Belirli Yanlış Kavrama ile } \\
\text { Birlikte Kısmi Anlama (AK/KA) }\end{array}$ & $\begin{array}{l}\text { Geçerli cevabın bazı yönleriyle birlikte bazı yanlış anlamaları içeren } \\
\text { cevaplar. }\end{array}$ \\
\hline Belirli Yanlış Kavrama (AK) & Mantıksız ve doğru olmayan bilgi içeren cevaplar. \\
\hline Anlamama (AN) & $\begin{array}{l}\text { Boş bırakma, bilmiyorum, anlamadım şeklindeki ve soruyu aynen } \\
\text { tekrarlama, ilgisiz ya da açık olmayan cevaplar. }\end{array}$ \\
\hline
\end{tabular}

IKKAT'nin kodlanmasında öğrencilerin cevapladıkları seçenekler ve seçeneklere ait yaptıkları açıklamalar, tam cevabı belirleme ve açılamaları belli kategoriler içerisinde sınıflandırma yaklaşımları kullanılarak analiz edilmiştir (Abraham ve diğ., 1992). Bu değerlendirme kriterlerinde aşağ1daki işlem sırası izlemiştir.

- Soruların olası doğru cevapları çıkarılmıştır.

- Öğrencilerin cevapları kodlanabilen ve kodlanamayan olarak ayrılmiştır. 
- Kodlanabilen cevaplar, doğru ve yanlış olarak ayrılmıştır.

- Doğru cevaplar içinde benzer açıklamalar sınıflandırılarak farklı cevap kategorileri oluşturulmuştur.

- Yanlış cevaplar kendi içerisinde sinıflandırılarak farklı kategorileri oluşturmuştur.

IKKAT'ın ilk kısmındaki doğru seçeneğe 1 puan, yanlış seçeneğe 0 puan verilmiştir. Öğrencilerin her bir sorudan ve testtin toplamından alacakları puanları hesaplamada Er Nas, Çalık ve Çepni (2012)'nin kullandığı düzeyler kullanılmıştır (Bakırcı, 2014). Bu düzeyler ve her bir düzeye kaç puan verildiği Tablo 3'teverilmiştir.

Tablo 3. Öğrencilerin IKKAT'tan Alacaklan Puanlan Hesaplamak İçin Kullanılan Dïzeyler

\begin{tabular}{ll}
\hline Düzeyler & Puan \\
\hline Doğru Cevap - Tam Anlama & $5(1+4)$ \\
\hline Doğru Cevap- Kısmi Anlama & $4(1+3)$ \\
\hline Doğru Cevap- Belirli Yanlış Kavrama ile Birlikte Kısmi Anlama & $3(1+2)$ \\
\hline Doğru Cevap- Belirli Yanlş Kavrama & $2(1+1)$ \\
\hline Doğru Cevap- Anlamama & $1(1+0)$ \\
\hline Yanlş Cevap- Tam Anlama & $4(0+4)$ \\
\hline Yanlş Cevap- Kısmi Anlama & $3(0+3)$ \\
\hline Yanlş̧ Cevap- Belirli Yanlış Kavrama ile Birlikte Kısmi Anlama & $2(0+2)$ \\
\hline Yanlş Cevap- Belirli Yanlış Kavrama & $1(0+1)$ \\
\hline Yanlş̧ Cevap- Anlamama & $0(0+0)$ \\
\hline
\end{tabular}

Öğrencilerin IKKAT'ta verecekleri cevaplar yukarıda Tablo 3'te verilen düzeylerden yararlanılarak puanlandırılmış ve istatistikî işlemler SPSS paket programı kullanılarak yapılmıştır. IKKAT"den elde edilen verilerin normal dağılıma uygun olup olmadığını belirlemek için normallik testi yapılmış veriler normal dağılım gösterdiği için deney ve kontrol grubuna uygulanan IKKAT'tan elde edilen verilerin gruplar arası karşılaştırmaları bağımsız t- testi kullanılarak analiz edilmiştir.

\section{Araştırmanın Uygulanması}

Araştırma 6 ders saati deney grubunda, 6 ders saati kontrol grubunda olmak üzere. üç hafta sürmüştür. Deney grubunda OBYM'ye göre fen öğretimi yapılmış, ışık konusunun öğretimi OBYM destekli etkinliklerle yürütülmüştür. OBYM, 4 aşamadan oluşmaktadır; (1) keşfetme ve sınıflandırma, 
(2) yapilandırma ve müzakere etme, (3) transfer etme ve genişletme, (4) yansitma ve değerlendirme. Modelin birbirini takip eden dört aşaması, her aşamanın amaçları ve fen bilimleri dersi öğretim programında yer alan kazanımlara uygun olarak Bakırcı(2014) tarafından geliştirilen materyaller ( Çalışma Yaprakları ,Kavramsal Değişim Metinleri, Kavram Karikatürleri, Analojiler, Kelime İlişkilendirme Testleri) kullanılmıştır. Kontrol grubunda ise 2013 Fen Bilimleri Dersi Öğretim Programı'na uygun olarak 5E öğretim modeline göre dersler yürütülmüştür. 5E öğretim modeline göre planlanan derslerde konuyla ilgili etkinlikler Milli Eğitim Bakanlığı'nın önerdiği fen bilimleri ders kitabından ve öğrenci çalışma kitabından alınmıştır.

OBYM ile 5E öğretim modelinin kıyaslanmasının nedeni, fen bilimleri öğretmenlerinin derslerinde 2005 yılından itibaren 5E öğretim modelini kullanıyor olmalarıdır. Dersler, hem deney hem de kontrol gruplarında araştırmacı tarafından işlenmiştir. Işık konusu kavramsal anlama testi( IKKAT) uygulama başlamadan önce deney ve kontrol grubuna ön test olarak uygulanmıştır. Uygulama bittikten sonra, aynı testi deney ve kontrol grubuna son test olarak uygulanmıştır.

\section{Bulgular}

Bu bölümde "Ortak bilgi yapılandırma modelinin 6. sınıf öğrencilerinin kavramsal anlamalarına etkisni belirlemeye yönelik hazırlanan Işık Konusu Kavramsal Anlama Testi (IKKAT) ‘den elde edilen bulgular yer almaktadır.

IKKAT ile elde edilen verilerin, deney ve kontrol grupları arasındaki karşılaştırmalarında bağımsız t-testi kullanılmıştır. Deney ve kontrol gruplarının IKKAT ön test ve son testleri arasındaki bağımsız t- testi sonuçları Tablo 4.'degösterilmiştir..

Tablo 4. Deney ve Kontrol Gruplarnın IKKAT Ön Test ve Son Test Puanları Arasındaki Bă̆ımsız t-Testi Sonuçlan

\begin{tabular}{|c|c|c|c|c|c|c|c|}
\hline TEST & GRUP & $\mathrm{N}$ & $X$ & Ss & $\mathrm{sd}$ & $\mathrm{T}$ & $p$ \\
\hline \multirow{2}{*}{ Ön Test } & Deney & 33 & 6,55 & 3,29 & \multirow{2}{*}{62} & \multirow{2}{*}{0,36} & \multirow{2}{*}{0,717} \\
\hline & Kontrol & 31 & 6,25 & 3,01 & & & \\
\hline \multirow{2}{*}{ Son Test } & Deney & 33 & 17,30 & 3,39 & \multirow{2}{*}{62} & \multirow{2}{*}{2,13} & \multirow{2}{*}{0,037} \\
\hline & Kontrol & 31 & 15,35 & 3,90 & & & \\
\hline
\end{tabular}


Tablo 4'de görüldüğü gibi kontrol ve deney gruplarının ön test puanları için yapılan bağımsız t-testi sonucunda gruplar arasında kavramsal anlama açısından istatistiksel olarak anlamlı bir fark bulunamamıştır $\left[\mathrm{t}_{(62)}=0,36\right.$, $\mathrm{p}>$.05]. Bu bulgu, uygulama öncesinde araştırmaya katılan öğrencilerin kavramsal anlamalarının aynı düzeyde olduğunu göstermektedir.

Tablo 4'de görüldüğü gibi uygulama sonrasinda deney ve kontrol grubuna uygulanan IKKAT'nin son test puanları arasinda deney grubu lehine istatistiksel olarak anlamlı bir fark bulunmuştur [ $\left.\mathrm{t}_{(62)}=2,99, \mathrm{p}<.05\right]$. Analiz sonuçlarına göre deney grubunda uygulanan OBYM'nin 6. sınıf öğrencilerin kavramsal anlamaları üzerinde etkisinin kontrol grubunda uygulanan 5E'ye göre daha fazla olduğu söylenebilir.

Kavramsal anlama ile ilgili verileri daha iyi değerlendirebilmek için IKKAT'te yer alan soru ve sorunun olası cevapları şekil olarak verilmiştir. Deney ve kontrol grubu öğrencilerinin sorunun çoktan seçmeli kısmına verdikleri cevapların yüzdeleri ayrı ayrı tablolarda gösterilmiştir. Deney ve kontrol grubu öğrencilerinin sorunun açıklama kısmına yaptıkları açılamalar için oluşturulan cevap kategorilerinin yüzdeleri ve öğrenci açıklamaları da tablolar şeklinde verilmiştir.

IKKAT'ta sorulan 1 . soruya yönelik elde edilen bulgular aşağıda verilmiştir.
Soru 1. Aşağıda, Işık ile ilgili yapılan tanımlardan hangisi doğrudur?
A) Işık, elektrikle çalışan bir yapıdır.
B) Işık, yapı itibariyle bir madde sayılır.
C) Işık; güneş, ampul, mum gibi kaynakların ortaya çıkardığı bir etkidir.
D) Işık, cam ve su gibi maddelerden geçen, boşlukta yayılan bir enerjidir.

Sorunun olası doğru cevabı: Işık kavramının tanımı ile ilgili literatürde rastlanılan alternatif kavramlardan hareketle hazırlanan bu soruda, öğrencilerin ışığın bir enerji türü olduğunu fark edip edemedikleri ile ilgili düşünceleri araştırılmıştır. Dolayısıyla öğrencilerin "Işık, cam ve su gibi maddelerden geçen, boşlukta yayılan bir enerjidir." Başka bir ifadeyle, "Çevremizdeki cisimleri görmemize ve renkleri ayırt etmemize yarayan bir enerjidir." ifadelerine benzer ifadeler kullanarak soruyu cevaplamaları beklenmektedir. Diğer taraftan "Işık; saydam ve yarı saydam maddelerden geçebilen, saydam olmayan ise maddelerden yansıyabilen bir enerji çeşidi" şeklinde cevaplar yazmaları beklenmektedir.

Şekil 1. IKKAT'ta Sorulan Birinci Soru ve Sorunun Olası Doğru Cevabı (Bakırcı, 2014) 
Deney grubunda birinci sorunun çoktan seçmeli kısma ait cevapların frekans ve yüzdeleri Tablo 5'de gösterilmiştir.

Tablo 5. Deney Grubu Öğrencilerinin Birinci Soru İçin Ön Test ve Son Testte Vermiş Olduklarn Çoktan Seçmeli Cevaplarn Frekans ve Yüzdeleri

\begin{tabular}{lllll}
\hline Cevaplar & \multicolumn{2}{c}{ Ön Test } & \multicolumn{2}{c}{ Son test } \\
\hline A) Işık, elektrikle çalışan bir yapıdır & $\mathrm{f}$ & $\%$ & $\mathrm{f}$ & $\%$ \\
\hline B) Işık, yapı itibariyle bir madde sayılır. & 8 & 24,24 & 3 & 9,09 \\
\hline $\begin{array}{l}\text { C) Işı; güneş, ampul, mum gibi kaynakların ortaya çıkardığı } \\
\text { bir etkidir. }\end{array}$ & 2 & 6,06 & - & - \\
\hline $\begin{array}{l}\text { D) Işık, cam ve su gibi maddelerden geçen, boşlukta yayılan } \\
\text { bir enerjidir }\end{array}$ & 6 & 17,18 & 27 & 81,81 \\
\hline Yanıt Yok & - & - & 3,09 \\
\hline Toplam & 33 & 100 & 33 & - \\
\hline
\end{tabular}

Tablo 5.'de görüldüğü gibi, öğrencilerin ışığın tanımı hakkındaki düşüncelerinin araştırıldığı bu soruyu ön testte deney grubu öğrencilerinin \%18,18'i doğru cevaplamışlardır. Yanlış cevap verenlerin içerisinde ilk sırayı $(\% 51,51)$ "Işı; güneş, ampul, mum gibi kaynakların ortaya çıkardığı bir etkidir." seçeneği almıştır. Son testte öğrencilerin \%81,81'inin birinci soruyu doğru cevapladıkları görülmektedir.

Kontrol grubunun birinci sorusundan elde edilen çoktan seçmeli kısma ait cevapların frekans ve yüzdeleri Tablo 6'da gösterilmiştir.

Tablo 6. Kontrol Grubu Öğrencilerinin Birinci Soru İçin Ön Test ve Son Testte Vermiş Olduklarn Çoktan Seçmeli Cevaplarn Frekans ve Yüzdeleri

\begin{tabular}{lllll}
\hline Cevaplar & \multicolumn{2}{c}{ Ön Test } & \multicolumn{2}{c}{ Son test } \\
\hline A) Işık, elektrikle çalışan bir yapıdır & $\mathrm{f}$ & $\%$ & $\mathrm{f}$ & $\%$ \\
\hline B) Işık, yapı itibariyle bir madde sayılır. & 7 & 22,58 & 1 & 3,22 \\
\hline $\begin{array}{l}\text { C) Işı; güneş, ampul, mum gibi kaynakların ortaya } \\
\text { çkardığı bir etkidir. }\end{array}$ & 3 & 9,67 & - & - \\
\hline $\begin{array}{l}\text { D) Işık, cam ve su gibi maddelerden geçen, boşlukta } \\
\text { yayılan bir enerjidir }\end{array}$ & 15 & 48,38 & 5 & 16,12 \\
\hline Yanıt Yok & 6 & 19,35 & 25 & 80,64 \\
\hline Toplam & - & & - & - \\
\hline
\end{tabular}

Tablo 6'da görüldüğü gibi, öğrencilerin 1şığın tanımı hakkındaki düşüncelerinin araştırıldığı bu soruyu ön testte kontrol grubu öğrencilerinin \%19,35'i doğru cevaplamışlardır. Yanlış cevap verenlerin içerisinde ilk sırayı 
$(\% 48,38)$ "Işık; güneş, ampul, mum gibi kaynakların ortaya çıkardığı bir etkidir." seçeneği almıştır. Son testte öğrencilerin \%80,64'ünün birinci soruyu doğru cevapladıkları görülmektedir.

Deney grubu öğrencilerinin IKKAT'ın birinci sorusu için yaptıkları açıklamalardan oluşturulan cevap kategorilerinin ön test ve son testteki frekans ve yüzdeleri Tablo 7 'de gösterilmiştir.

Tablo 7. Deney Grubu Öğrencilerinin Kavramsal Anlama Testi 1. Sorusuna Yaptıkları Açıklamalar İçin Oluşturulan Cevap Kategorilerinin Frekans ve Yüzdeleri

\begin{tabular}{|c|c|c|c|c|c|}
\hline Düzey & Kategoriler( $\mathrm{N}=33)$ & \multicolumn{2}{|c|}{ Ön Test } & \multicolumn{2}{|c|}{ Son test } \\
\hline \multirow{3}{*}{ TA } & & $\mathrm{f}$ & $\%$ & $\mathrm{f}$ & $\%$ \\
\hline & $\begin{array}{l}\text { Işık saydam ve yarı saydam maddelerden geçebilen, } \\
\text { opak maddelerden geçemeyen, } \\
\text { boşlukta yayılan bir enerjidir. }\end{array}$ & - & - & 16 & 48,48 \\
\hline & $\begin{array}{l}\text { Işık bir enerjidir. Cisimlerden gözümüze gelerek } \\
\text { cisimleri görmemizi sağlar. }\end{array}$ & - & - & 7 & 21,21 \\
\hline$K A$ & $\begin{array}{l}\text { Doğal ve yapay ışık kaynakları vardır ve etrafa ışık } \\
\text { yayarlar. }\end{array}$ & 5 & 15,15 & 3 & 9,09 \\
\hline KA & $\begin{array}{l}\text { Işık boşlukta yarılır. Dünyamızın aydınlanmasını } \\
\text { ve ısınmasını sağlar. }\end{array}$ & 4 & 12,12 & 3 & 9,09 \\
\hline $\mathrm{AK} / \mathrm{KA}$ & Işık birçok maddeden yayılan bir etkidir. & 2 & 6,06 & - & - \\
\hline AK/KA & Işık boşlukta yayılabilen ve yansıyabilen bir maddedir. & 2 & 6,06 & 1 & 3,03 \\
\hline AK & $\begin{array}{l}\text { Işık elektrikle çalışan bir yapıdır. Çünkü elektrik } \\
\text { kesilince ışıklar söner. Elektrik varken ışık yanar. }\end{array}$ & 10 & 30,30 & 1 & 3,03 \\
\hline$\Delta \mathrm{NI}$ & Açıklama yok & 8 & 24,24 & 1 & 3,03 \\
\hline AIV & Alakasız cevap & 2 & 6,06 & - & - \\
\hline Toplam & & 33 & 100 & & 100 \\
\hline
\end{tabular}

Tablo 7 incelendiğinde ön testte öğrencilerin \%27,27'si kısmi anlama(KA), \%12,12'si alternatif kavram ile kısmi anlama (AK/KA), \%30,30'u alternatif kavram (AK), \%30,30'u anlamama (AN) kategorilerine giren cevaplar verirken, tam anlama (TA) kategorisinde cevap veren olmamıştır. Son testte, öğrencilerin \%69,70'inin tam anlama, \%18,18'inin k1smi anlama, \%3,03'ünün alternatif kavram ile kısmen anlama, \%3,03'ünün alternatif kavram ve \%3,03'ünün anlamama kategorilerine giren cevaplar verdiği tespit edilmiştir.

Kontrol grubu öğrencilerinin IKKAT'ın birinci sorusunda ön test ve son testte yaptıkları açıklamalar için oluşturulan cevap kategorilerinin frekans ve yüzdeleri Tablo 8 'de gösterilmiştir. 
Tablo 8. Kontrol Grubu Öğrencilerinin Kavramsal Anlama Testi 1. Sorusuna Yaptıklarn Açılamalar İçin Oluşturulan Cevap Kategorilerinin Frekans ve Yüzdeleri

\begin{tabular}{|c|c|c|c|c|c|}
\hline Düzey & Kategoriler(N=31) & Ön & & Sor & test \\
\hline \multirow{4}{*}{ TA } & & $\mathrm{f}$ & $\%$ & $\mathrm{f}$ & $\%$ \\
\hline & Işık boşlukta yayılan, saydam maddelerden geçen enerjidir. & - & - & 8 & 25,80 \\
\hline & Cisimlerden yansıyarak görmemizi sağlayan bir enerjidir. & - & - & 4 & 12,90 \\
\hline & $\begin{array}{l}\text { Işık kaynakları tarafından üretilen ve doğrusal yolla yayılan } \\
\text { enerjidir. }\end{array}$ & - & - & 3 & 9,68 \\
\hline \multirow{2}{*}{ KA } & Opak maddelerden geçemez, saydam maddelerden geçer. & 1 & 3,23 & 4 & 12,90 \\
\hline & Açık renkli maddeler ışığı daha çok yansıtır. & - & - & 1 & 3,23 \\
\hline \multirow{2}{*}{$\mathrm{AK} / \mathrm{KA}$} & Doğal ve yapay 1şık kaynaklarının ürettiği şeydir. & 8 & 25,80 & 4 & 12,90 \\
\hline & Işık etrafı aydınlatır. Bazı maddelerden geçemez. & 2 & 6,45 & 3 & 9,68 \\
\hline \multirow[t]{2}{*}{ AK } & $\begin{array}{l}\text { Işık elektrikle çalışır. Çünkü elektrik düğmesine basınca ışık } \\
\text { yanar. }\end{array}$ & 7 & 22,58 & 1 & 3,23 \\
\hline & Işık etrafı aydınlatan bir maddedir. & 3 & 9,68 & 1 & 3,23 \\
\hline \multirow{2}{*}{ AN } & Açıklama yok & 6 & 19,35 & 2 & 6,45 \\
\hline & Alakasız cevap & 4 & 12,90 & - & - \\
\hline Toplam & & 31 & 100 & 31 & 100 \\
\hline
\end{tabular}

Tablo 8 incelendiğinde ön testte öğrencilerin \%3,23'ü kısmi anlama(KA), \%32,26's1 alternatif kavram ile kismi anlama (AK/KA), \%32,26's1 alternatif kavram (AK), \%32,26'sı anlamama (AN) kategorilerine giren cevaplar verirken, tam anlama (TA) kategorisinde cevap veren olmamıştır. Son testte, öğrencilerin \%48,39'unun tam anlama, \%16,13'ünün kısmi anlama, $\% 22,58$ 'inin alternatif kavram ile k1smen anlama, \%6,45'inin alternatif kavram ve $\% 6,45$ inin anlamama kategorilerine giren cevaplar verdiği tespit edilmiştir.

Tablo 7 ve Tablo 8'deki analiz sonuçları incelendiğinde IKKAT'ın 1. Sorusuna göre OMYM'nin alternatif kavramları gidermede ve tam anlamayı sağlamada daha etkili olduğu görülmüştür.

IKKAT'ta sorulan 2. soruya yönelik elde edilen bulgular aşağıda verilmiştir. 


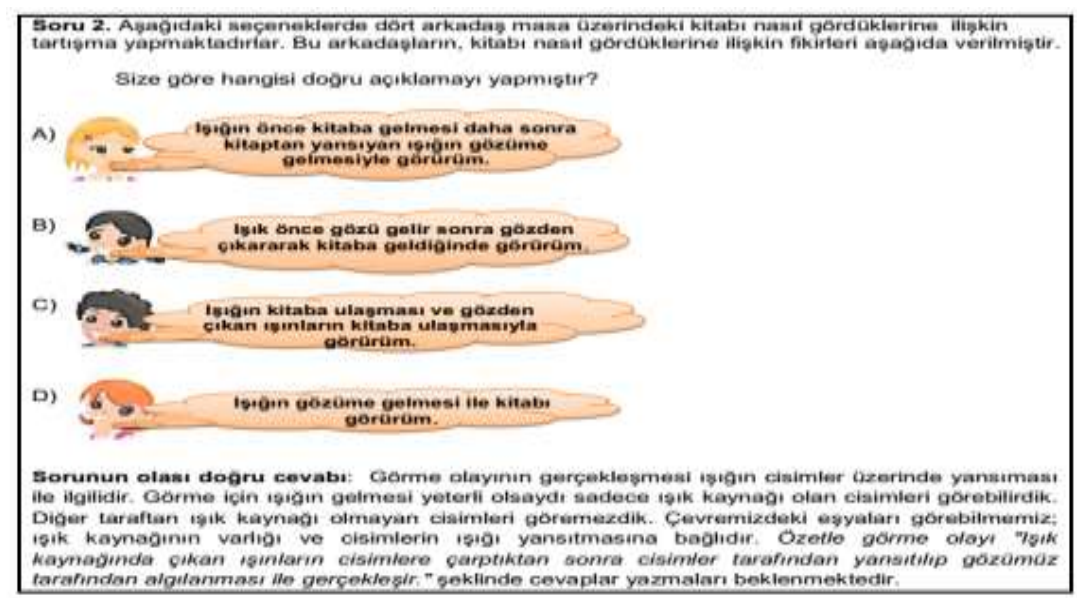

Şekil 2. KKAT'ta Sorulan İkinci Soru ve Sorunun Olası Doğru Cevabı (Bakırcı, 2014)

Deney grubunun ikinci sorusundan elde edilen çoktan seçmeli kısma ait cevapların frekans yüzdeleri Tablo 9.'da gösterilmiştir.

Tablo 9.Deney Grubu Öğrencilerinin 2. Soru İçin Ön Test ve Son Testte Vermiş Olduklarn Çoktan Seçmeli Cevaplarn Frekans ve Yüzdeleri

\begin{tabular}{|c|c|c|c|c|c|}
\hline \multirow[t]{2}{*}{ Cevaplar } & & \multicolumn{2}{|c|}{ Ön Test } & \multicolumn{2}{|c|}{ Son test } \\
\hline & & $\mathrm{f}$ & $\%$ & $\mathrm{f}$ & $\%$ \\
\hline A) & $\begin{array}{l}\text { Işığın önce kitaba gelmesi daha sonra kitaptan yansıyan ışı- } \\
\text { ğın gözüme gelmesi ile görürüm. }\end{array}$ & 5 & 15,15 & 28 & 84,84 \\
\hline B) & $\begin{array}{l}\text { Işık önce göze gelir sonra gözden çkarak kitaba geldiğinde } \\
\text { görürüm. }\end{array}$ & 6 & 18,18 & 1 & 3,03 \\
\hline C) & $\begin{array}{l}\text { Işığın kitaba ulaşması ve gözden çıkan ışınların kitaba } \\
\text { ulaşması ile görürüm. }\end{array}$ & 12 & 36,36 & 4 & 12,12 \\
\hline D) & Işığın gözüme gelmesi ile kitabı görürüm. & 5 & 15,15 & - & - \\
\hline Yanit Yok & & 5 & 15,15 & - & - \\
\hline Toplam & & 33 & 100 & 33 & 100 \\
\hline
\end{tabular}

Tablo 9'da görüldüğü gibi, öğrencilerin görme olayının nasıl gerçekleştiğine ilişkin düşüncelerinin araştırıldığı bu soruyu ön testte deney grubu öğrencilerinin \%15,15'i doğru cevaplamışlardır. Yanlış cevap verenlerin içerisinde ilk sırayı $(\% 36,36)$ " Işığın kitaba ulaşması ve gözden çıkan ışınların kitaba ulaşması ile görürüm." seçeneği almıştır. Son testte öğrencilerin \%84,84'ünün ikinci soruyu doğru cevapladıkları görülmektedir.

Kontrol grubunun ikinci sorusundan elde edilen çoktan seçmeli kısma ait cevapların frekans ve yüzdeleri Tablo 10'da gösterilmiştir. 
Tablo 10. Kontrol Grubu Öğrencilerinin 2. Soru İçin Ön Test ve Son Testte Vermiş Oldukları Çoktan Seçmeli cevaplarn Frekans ve Yüzdeleri

\begin{tabular}{|c|c|c|c|c|c|}
\hline \multirow[t]{2}{*}{ Cevaplar } & & \multicolumn{2}{|c|}{ Ön Test } & \multicolumn{2}{|c|}{ Son test } \\
\hline & & $\mathrm{f}$ & $\%$ & $\mathrm{f}$ & $\%$ \\
\hline A) & $\begin{array}{l}\text { Işığın önce kitaba gelmesi daha sonra kitaptan } \\
\text { yansıyan ışı̆ı̆n gözüme gelmesi ile görürüm. }\end{array}$ & 4 & 12,90 & 24 & 77,42 \\
\hline B) & $\begin{array}{l}\text { Işık önce göze gelir sonra gözden çıkarak kitaba } \\
\text { geldiğinde görürüm. }\end{array}$ & 7 & 22,58 & 3 & 9,67 \\
\hline C) & $\begin{array}{l}\text { Işı̆̆ın kitaba ulaşması ve gözden çıkan ışınların } \\
\text { kitaba ulaşması ile görürüm. }\end{array}$ & 6 & 19,35 & 2 & 6,45 \\
\hline D) & Işı̆̆ın gözüme gelmesi ile kitabı görürüm. & 11 & 35,48 & 2 & 6,45 \\
\hline Yanit Yok & & 3 & 9,67 & - & - \\
\hline Toplam & & 31 & 100 & 31 & 100 \\
\hline
\end{tabular}

Tablo 10'da görüldüğü gibi, öğrencilerin görme olayının nasıl gerçekleştiğine ilişkin düşüncelerinin araştırıldığı bu soruyu ön testte kontrol grubu öğrencilerinin \%12,90'1 doğru cevaplamışlardır. Yanlış cevap verenlerin içerisinde ilk sırayı $(\% 35,48)$ " Işığın gözüme gelmesi ile kitabı görürüm." seçeneği almıştır. Son testte öğrencilerin \%77,42'sinin ikinci soruyu doğru cevapladıkları görülmektedir.

Deney grubu öğrencilerinin IKKAT'ın ikinci sorusu için yaptıkları açılamalardan oluşturulan cevap kategorilerinin ön test ve son testteki frekans ve yüzdeleri Tablo 11'de gösterilmiştir.

Tablo 11. Deney Grubu Öğrencilerinin Kavramsal Anlama Testi 2. Sorusuna Yaptıklan Açıklamalar İçin Oluşturulan Cevap Kategorilerinin Frekans ve Yüzdeleri

\begin{tabular}{|c|c|c|c|c|c|}
\hline \multirow{2}{*}{$\begin{array}{l}\text { Düzey } \\
\text { TA }\end{array}$} & \multirow[t]{2}{*}{ Kategoriler(N=33) } & \multicolumn{2}{|c|}{ Ön Test } & \multicolumn{2}{|c|}{ Son test } \\
\hline & & $\mathrm{f}$ & $\%$ & $\mathrm{f}$ & $\%$ \\
\hline & $\begin{array}{l}\text { Işığın önce cisme gelmesi sonra cisimden yansıyan 1şığın } \\
\text { göze gelmesi ile görürüz. }\end{array}$ & 1 & 3,03 & 20 & 60,60 \\
\hline & $\begin{array}{l}\text { Işık önce cisme oradan da gözümüze gelirse görürüz. Işık } \\
\text { gözden çıkmaz. Öyle olsaydı karanlık yerleri gözümüzle } \\
\text { aydınlatabilirdik. }\end{array}$ & - & - & 5 & 15,15 \\
\hline \multirow[t]{2}{*}{ KA } & Cismi görmek için ışığa ihtiyacımız vardır. & 5 & 15,15 & 2 & 6,06 \\
\hline & Işı̆̆ın gözümüze gelmesi ile görürüz. & 7 & 21,21 & 3 & \\
\hline \multirow[t]{3}{*}{ AK } & Cismi görmek için ışığa ihtiyacımız vardır. & 4 & 12,12 & - & - \\
\hline & Gözden çkan 1şınla görürüz. & 3 & 9,09 & - & - \\
\hline & $\begin{array}{l}\text { Ne gözden 1şık çıkar, ne de göze ışık gelir. Işığın cisme } \\
\text { gitmesiyle görürüz. }\end{array}$ & 2 & 6,06 & 1 & 3,03 \\
\hline \multirow[t]{2}{*}{ AN } & Açıklama yok & 8 & 24,24 & 2 & 6,06 \\
\hline & Alakasız cevap & 3 & 9,09 & - & - \\
\hline Toplam & & 33 & 100 & 33 & 100 \\
\hline
\end{tabular}


Tablo 11 incelendiğinde ön testte öğrencilerin $\% 48,48$ 'i k1smi anlama(KA), \%27,27'si alternatif kavram (AK), \%33,33'ü anlamama (AN) kategorilerine giren cevaplar verirken, \%3,03'ü tam anlama (TA) kategorisinde cevap vermişlerdir. Son testte, öğrencilerin \%75,75'inin tam anlama, $\% 15,15^{\prime}$ inin kısmi anlama, \%3,03'ünün alternatif kavram ve \%6,06'sının anlamama kategorilerine giren cevaplar verdiği tespit edilmiştir

Kontrol grubu öğrencilerinin IKKAT'ın ikinci sorusu için yaptıkları açıklamalardan oluşturulan cevap kategorilerinin ön test ve son testteki frekans ve yüzdeleri Tablo 12'de verilmiştir.

Tablo 12. Kontrol Grubu Öğrencilerinin Kavramsal Anlama Testi 2. Sorusuna Yaptıklar Açıklamalar İçin Oluşturulan Cevap Kategorilerinin Frekans ve Yüzdeleri

\begin{tabular}{|c|c|c|c|c|c|}
\hline Düzey & Kategoriler(N=31) & \multicolumn{2}{|c|}{ Ön Test } & \multicolumn{2}{|c|}{ Son test } \\
\hline \multirow[b]{2}{*}{ TA } & & $\mathrm{f}$ & $\%$ & $\mathrm{f}$ & $\%$ \\
\hline & $\begin{array}{l}\text { Işık önce cisme gelir. Cisimden yansıyan ışığın göze gelmesi } \\
\text { ile görme gerçekleşir. 1şı̆̆ın göze gelmesi ile görürüz. }\end{array}$ & 2 & 6,45 & 16 & 51,61 \\
\hline \multirow{3}{*}{ KA } & Görmek için ışığın cisimlerden yansıması gerekir. & 5 & 16,12 & 5 & 16,12 \\
\hline & Karanlık bir odada hiçbir şey görülmez. & 4 & 12,90 & 1 & 3,22 \\
\hline & Görebilmek için gözümüze ışık çarpmalıdır. & 6 & 19,35 & 5 & 16,12 \\
\hline \multirow[b]{2}{*}{ AK } & Işık önce gözümüze gelirse cismi görürüz. & 5 & 16,12 & 2 & 6,45 \\
\hline & $\begin{array}{l}\text { Gözümüzden çıan ışınlar kitaptan yansır ve görme } \\
\text { gerçekleşir. }\end{array}$ & 5 & 16,12 & - & - \\
\hline \multirow{2}{*}{ AN } & Açılama yok & 4 & 12,90 & 2 & 6,45 \\
\hline & Alakasız cevap & 3 & 9,67 & - & - \\
\hline Toplam & & 31 & 100 & 31 & 100 \\
\hline
\end{tabular}

Tablo 12. incelendiğinde ön testte öğrencilerin $\% 48,39^{\prime} \mathrm{u}$ kısmi anlama(KA), \%32,25'i alternatif kavram (AK), \%22,58'i anlamama (AN) kategorilerine giren cevaplar verirken, $\% 6,45$ ' $\mathrm{i}$ tam anlama (TA) kategorisinde cevap vermişlerdir. Son testte, öğrencilerin \%51,61'inin tam anlama, $\% 35,48^{\prime}$ inin kısmi anlama, \%6,45'inin alternatif kavram ve \%6,45'inin anlamama kategorilerine giren cevaplar verdiği tespit edilmiştir.

Tablo 11 ve tablo 12 'deki analiz sonuçları incelendiğinde IKKAT'in 2. Sorusuna göre OMYM'nin alternatif kavramları gidermede ve tam anlamayı sağlamada daha etkili olduğu görülmüştür.

IKKAT'ta sorulan 3. soruya yönelik elde edilen bulgular aşağıda verilmiştir. 


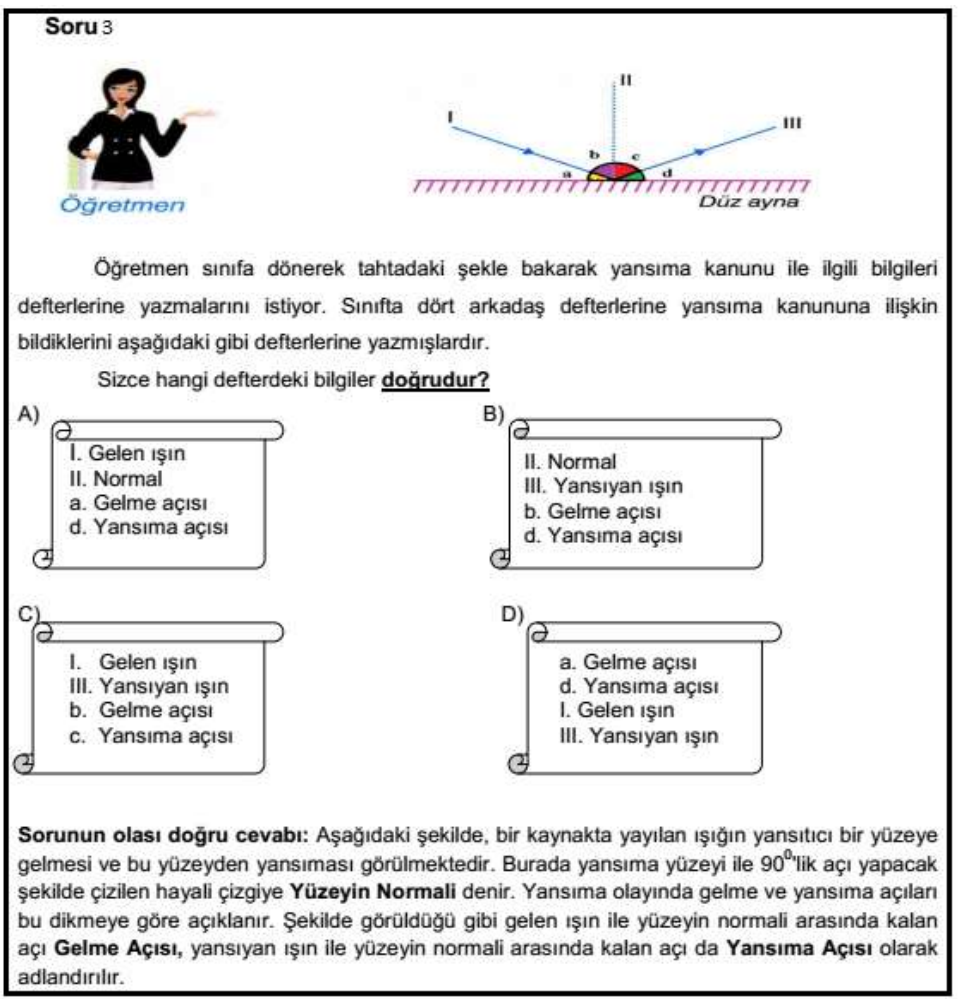

Şekil 3. IKKAT'ta Sorulan Üçüncü Soru ve Sorunun Olası Doğru Cevabı (Bakırcı, 2014)

Şekil 3'ün devamı;

Yansımanın iki kuralı vardır. Bunlar;

a) Gelen ışın, yansıyan ışın ve yüzeyin normali aynı dũzlemdedir.

b) Gelme açısı yansıma açısına eşittir.

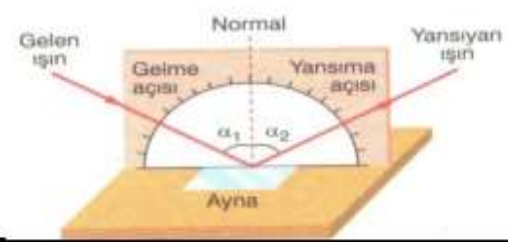

Deney grubu öğrencilerinin üçüncü sorusundan elde edilen çoktan seçmeli kısma ait cevaplarınn frekans ve yüzdeleri Tablo 13'de gösterilmiştir. 
Tablo 13. Deney Grubu Öğrencilerinin 3. Soru İçin Ön Test ve Son Testte Vermiş Oldukları Çoktan Seçmeli Cevaplarn Frekans ve Yüzdeleri

\begin{tabular}{lllll}
\hline Cevaplar & \multicolumn{2}{c}{ Ön Test } & \multicolumn{2}{c}{ Son test } \\
\hline & $\mathrm{f}$ & $\%$ & $\mathrm{f}$ & $\%$ \\
\hline A) I=Gelen 1şın, II=Normal, a= Gelme açısı, d= Yansıma açısı & 9 & 27,27 & - & - \\
\hline B) II= Normal, III= Yansıyan 1şın, b=Gelme açıSı, d=Yansıma açısı & 2 & 6,06 & 1 & 3,03 \\
\hline $\begin{array}{l}\text { C) I= Gelen ışın, III=Yansıyan 1şın, b=Gelme açıSı, } \\
\text { c=Yansıma açısı }\end{array}$ & 2 & 6,06 & 30 & 90,91 \\
\hline D) a=Gelme açısı, d=Yansıma açısı, I=Gelen ışın, III=Yansıyan 1şın & 7 & 21,21 & 2 & 6,06 \\
\hline Yanıt Yok & 13 & 39,39 & - & - \\
\hline Toplam & 33 & 100 & 33 & 100 \\
\hline
\end{tabular}

Tablo 13'de görüldüğü gibi, öğrencilerin yansıma kanunlarına ilişkin düşüncelerinin araştırıldığ $\% 6,06$ 'sı doğru cevaplamışlardır. \%39,39'unun ise soruya cevap vermedikleri görülmüştür. Son testte öğrencilerin \%90,91'inin üçüncü soruyu doğru cevapladıkları görülmektedir.

Kontrol grubu öğrencilerinin üçüncü sorusundan elde edilen çoktan seçmeli kısma ait cevapların frekans ve yüzdeleri Tablo 14' de gösterilmiştir.

Tablo 14. Kontrol Grubu Öğrencilerinin 3. Soru İçin Ön Test ve Son Testte Vermiş Oldukları Çoktan Seçmeli Cevaplarn Frekans ve Yüzdeleri

\begin{tabular}{lllll}
\hline Cevaplar & Ön Test & \multicolumn{2}{c}{ Son test } \\
\hline & $\mathrm{f}$ & $\%$ & $\mathrm{f}$ & $\%$ \\
\hline A) I=Gelen ışın, II=Normal, a= Gelme açısı, d= Yansıma açısı & 5 & 16,12 & 1 & 3,23 \\
\hline B) II= Normal, III= Yansıyan ışın, b=Gelme açısı, d=Yansıma açısı & 3 & 9,68 & - & - \\
\hline $\begin{array}{l}\text { C) I= Gelen 1şın, III=Yansıyan ışın, b=Gelme açısı, } \\
\text { c=Yansıma açısı }\end{array}$ & 4 & 12,90 & 27 & \multirow{2}{*}{87,10} \\
\hline D) a=Gelme açısı, d=Yansıma açısı, I=Gelen ışın, III=Yansıyan ışın & 10 & 32,26 & 3 & 9,68 \\
\hline Yanıt Yok & 9 & 29,03 & - & - \\
\hline Toplam & 31 & 100 & 31 & 100 \\
\hline
\end{tabular}

Tablo 14'de görüldüğü gibi, öğrencilerin yansıma kanunlarına ilişkin düşüncelerinin araştırıldığı bu soruyu ön testte kontrol grubu öğrencilerinin $\% 12,90$ 'n doğru cevaplamışlardır. \%32,26'sının ise D seçeneğini işaretledikleri görülmüştür. Son testte öğrencilerin \%87,10'unun üçüncü soruyu doğru cevapladıkları görülmektedir.

Deney grubu öğrencilerinin IKKAT'ın üçüncü sorusu için yaptıkları açıklamalardan oluşturulan cevap kategorilerinin ön test ve son testlerindeki frekans ve yüzdeleri Tablo15 'de gösterilmiştir. 
Tablo 15. Deney Grubu Öğrencilerinin Kavramsal Anlama Testi 3. Sorusuna Yaptıklarn Açılamalar İçin Oluşturulan Cevap Kategorilerinin Frekans ve Yüzdeleri

\begin{tabular}{|c|c|c|c|c|c|}
\hline \multirow[t]{2}{*}{ Düzey } & \multirow[t]{2}{*}{ Kategoriler(N=33) } & \multicolumn{2}{|c|}{ Ön Test } & \multicolumn{2}{|c|}{ Son test } \\
\hline & & $\mathrm{f}$ & $\%$ & $\mathrm{f}$ & $\%$ \\
\hline \multirow[t]{2}{*}{ TA } & $\begin{array}{l}\text { Aynaya gönderilen ışığın normal ile arasındaki açı gelme } \\
\text { açısı iken, yansıyan ışığın normal ile yaptığı açı ise yansıma } \\
\text { açısıdır. }\end{array}$ & 1 & 3,03 & 14 & 42,42 \\
\hline & Gelen ışın, yansıyan ışın ve normal aynı düzlemdedir & - & - & 6 & 18,18 \\
\hline \multirow[t]{2}{*}{$\mathrm{KA}$} & $\begin{array}{l}\text { Yansıma kanununa göre yüzeye gelen ışının gelme açısı, } \\
\text { yansıma açısına eşittir. }\end{array}$ & 4 & 12,12 & 7 & 21,21 \\
\hline & Yüzeyin normali aynaya daima diktir. & - & - & 3 & 9,09 \\
\hline $\mathrm{AK} / \mathrm{KA}$ & $\begin{array}{l}\text { Aynaya gönderilen ışın ile ayna arasında kalan açıya gelme } \\
\text { açısı denir. Yansıyan ışın ile ayna arasında kalan açıya ise } \\
\text { yansıma açısı denir. Gelme açısı yansıma açısına eşittir. }\end{array}$ & 10 & 30,30 & 2 & 6,06 \\
\hline AK & Ayna 1şı̆̆ın bir kısmını yutar. & 5 & 15,15 & - & - \\
\hline $\mathrm{AN}$ & Açıklama yok & 13 & 39,39 & 1 & 3,03 \\
\hline Toplam & & 33 & 100 & 33 & 100 \\
\hline
\end{tabular}

Tablo 15 incelendiğinde ön testte öğrencilerin \%12,12'si kısmi anlama(KA), \%30,30'u alternatif kavram ile kismi anlama (AK/KA), \%15,15'i alternatif kavram (AK), \%39,39'u anlamama (AN) kategorilerine giren cevaplar verirken, \%3,03'ü tam anlama (TA) kategorisinde cevap vermiştir. Son testte, öğrencilerin \%60,61'inin tam anlama, \%30,30'unun kısmi anlama, $\% 6,06$ 'sının alternatif kavram ile kısmen anlama ve \%3,03'ünün anlamama kategorilerine giren cevaplar verdiği tespit edilmiştir.

Kontrol grubu öğrencilerinin IKKAT'ın üçüncü sorusu için yaptıkları açıklamalardan oluşturulan cevap kategorilerinin ön test ve son testteki frekans ve yüzdeleri Tablo 16 'da gösterilmiştir.

Tablo 16. Kontrol Grubu Öğrencilerinin Kavramsal Anlama Testi 3. Sorusuna Yaptıklan Açıklamalar İçin Oluşturulan cevap Kategorilerinin Frekans ve Yüzdeleri

\begin{tabular}{|c|c|c|c|c|c|}
\hline \multirow{2}{*}{$\begin{array}{ll}\text { Düzey } \\
\text { TA }\end{array}$} & \multirow[t]{2}{*}{ Kategoriler(N=31) } & \multicolumn{2}{|c|}{ Ön Test } & \multicolumn{2}{|c|}{ Son test } \\
\hline & & $\mathrm{f}$ & $\%$ & $\mathrm{f}$ & $\%$ \\
\hline & $\begin{array}{l}\text { Aynaya gönderilen ışı̆̆ın normal ile arasındaki açı gelme açısı iken, yansıyan } \\
\text { ışı̆̆ın normal ile yaptı̆ı açı ise yansıma açısıdır. }\end{array}$ & 2 & 6,45 & 10 & 32,25 \\
\hline & Gelen ısın, yansıyan ısın ve normal aynı düzlemdedir & - & - & 8 & 25,80 \\
\hline \multirow[t]{2}{*}{ KA } & $\begin{array}{l}\text { Yansıma kanununa göre yüzeye gelen ışııın gelme açısı, yansıma açısına } \\
\text { eşittir. }\end{array}$ & 4 & 12,90 & 5 & 16,12 \\
\hline & Yüzeyin normali aynaya daima diktir. & - & - & 3 & 9,67 \\
\hline AK & $\begin{array}{l}\text { Aynaya gönderilen ışın ile ayna arasında kalan açıya gelme açısı denir. } \\
\text { Yansıyan ışın ile ayna arasında kalan açıya ise yansıma açısı denir. }\end{array}$ & 16 & 51,61 & 4 & 12,90 \\
\hline \multirow[t]{2}{*}{ AN } & Açıklama yok & 6 & 19,35 & 1 & 3,23 \\
\hline & Alakasız cevap & 3 & 9,67 & - & - \\
\hline Toplam & & 31 & 100 & 31 & 100 \\
\hline
\end{tabular}


Tablo 16. incelendiğinde ön testte öğrencilerin \%12,90'1 kısmi anlama(KA), \%51,61'i alternatif kavram (AK), \%29,03'ü anlamama (AN) kategorilerine giren cevaplar verirken, $\% 6,45^{\prime} \mathrm{i}$ tam anlama (TA) kategorisinde cevap vermiştir. Son testte, öğrencilerin $\% 58,06$ 'sının tam anlama, $\% 25,80^{\prime}$ inin kısmi anlama, \%12,90'ının alternatif kavram ve \%3,23'ünün anlamama kategorilerine giren cevaplar verdiği tespit edilmiştir.

Tablo 15 ve Tablo 16'daki analiz sonuçları incelendiğinde IKKAT'ın 3. Sorusuna göre OMYM'nin alternatif kavramları gidermede ve tam anlamay1 sağlamada daha etkili olduğu görülmüştür.

IKKAT'ta sorulan 4. soruya yönelik elde edilen bulgular aşağıda verilmiştir.

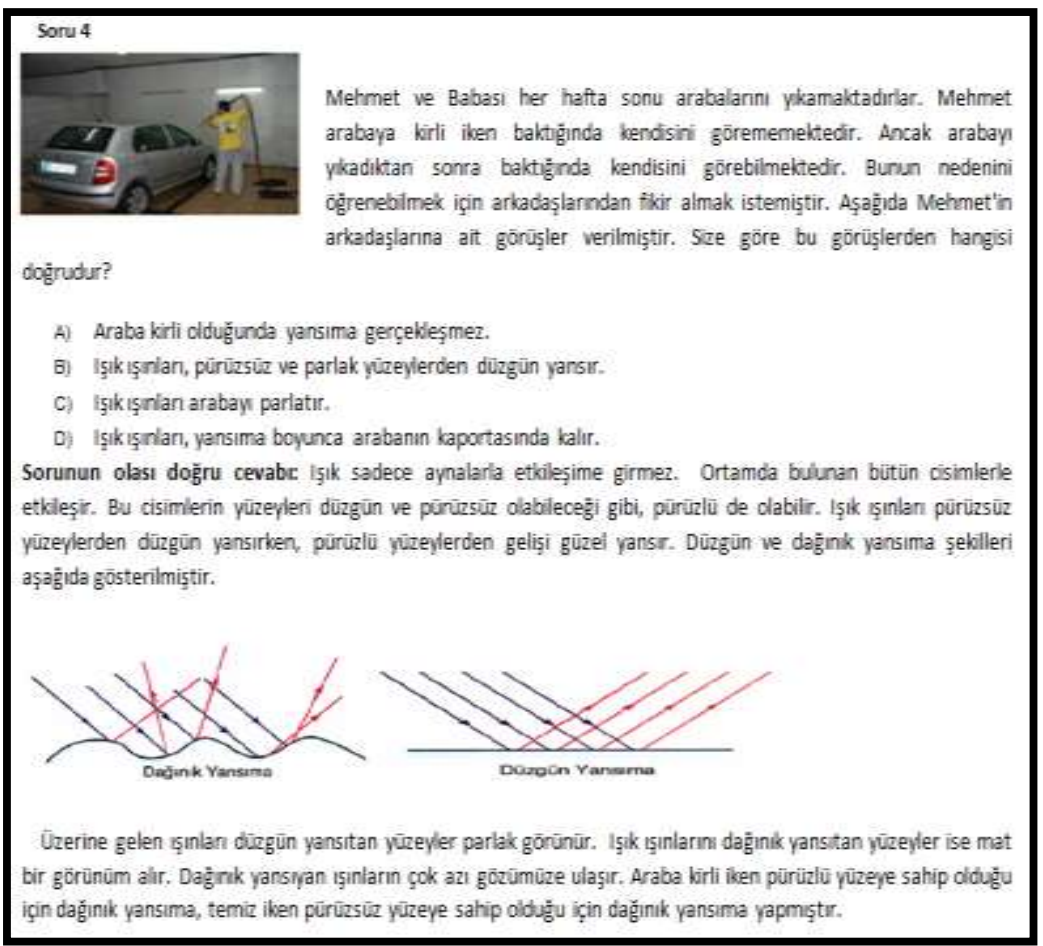

Şekil 4. IKKAT'ta Sorulan Dördüncü Soru ve Sorunun Olası Doğru Cevabı Bakırcı, 2014)

Deney grubu öğrencilerinin dördüncü sorusundan elde edilen çoktan seçmeli kısma ait cevapların frekans ve yüzdeleri Tablo 17'de gösterilmiştir. 
Tablo 17. Deney Grubu Öğrencilerinin 4. Soru İçin Ön Test ve Son Testte Vermiş Oldukları Çoktan Seçmeli Cevaplarn Frekans ve Yüzdeleri

\begin{tabular}{lllll}
\hline Cevaplar & \multicolumn{2}{l}{ Ön Test } & \multicolumn{2}{l}{ Son test } \\
\hline A)Araba kirli olduğunda yansıma gerçekleşmez. & $\mathrm{f}$ & $\%$ & $\mathrm{f}$ & $\%$ \\
\hline B)Işık ışınları, pürüzsüz ve parlak yüzeylerden düzgün yansır. & 14 & 42,42 & 3 & 9,09 \\
\hline C)Işık ışınları arabayı parlatır. & 4 & 12,12 & 29 & 87,88 \\
\hline D)Işık ışınları, yansıma boyunca arabanın kaportasında kalır. & 5 & 15,15 & 1 & 3,03 \\
\hline Yanıt Yok & 3 & 9,09 & - & - \\
\hline Toplam & 7 & 21,21 & - & - \\
\hline
\end{tabular}

Tablo 17'de görüldüğü gibi, öğrencilerin düzgün ve dağınık yansımaya ilişkin düşüncelerinin araştırıldığı bu soruyu ön testte deney grubu öğrencilerinin \%12,12'si doğru cevaplamışlardır. \%42,42'sinin ise A seçeneğini işaretledikleri görülmüştür. Son testte öğrencilerin $\% 87,88^{\prime}$ inin dördüncü soruyu doğru cevapladıkları görülmektedir.

Kontrol grubu öğrencilerinin dördüncü sorusundan elde edilen çoktan seçmeli kısma ait cevapların frekans ve yüzdeleri Tablo 18 'de gösterilmiştir.

Tablo 18. Kontrol Grubu Öğrencilerinin 4. Soru İçin Ön Test ve Son Testte Vermiş Oldukları Çoktan Seçmeli Cevaplarn Frekans ve Yüzdeleri

\begin{tabular}{lllll}
\hline Cevaplar & \multicolumn{2}{l}{ Ön Test } & \multicolumn{2}{l}{ Son test } \\
\hline & $\mathrm{f}$ & $\%$ & $\mathrm{f}$ & $\%$ \\
\hline A)Araba kirli olduğunda yansıma gerçekleşmez. & 7 & 22,58 & - & - \\
\hline B)Işık ışınları, pürüzsüz ve parlak yüzeylerden düzgün yansır. & 4 & 12,90 & 27 & 87,10 \\
\hline C)Işık ş̧ınları arabayı parlatır. & 2 & 6,45 & 1 & 3,23 \\
\hline D)Işık ışınları, yansıma boyunca arabanın kaportasında kalır. & 16 & 51,61 & 3 & 9,68 \\
\hline Yanıt Yok & 2 & 6,45 & - & - \\
\hline Toplam & 31 & 100 & 31 & 100 \\
\hline
\end{tabular}

Tablo18'de görüldüğü gibi, öğrencilerin düzgün ve dağınık yansımaya ilişkin düşüncelerinin araştırıldığı bu soruyu ön testte kontrol grubu öğrencilerinin \%12,90'nı doğru cevaplamışlardır. \%51,61'inin ise D seçeneğini işaretledikleri görülmüştür. Son testte öğrencilerin \%87,10'ununn dördüncü soruyu doğru cevapladıkları görülmektedir.

Deney grubu öğrencilerinin IKKAT'ın dördüncü sorusu için yaptıkları açıklamalardan oluşturulan cevap kategorilerinin ön test ve son testlerindeki frekans ve yüzdeleri Tablo 19'da gösterilmiştir. 
Tablo 19. Deney Grubu Öğrencilerinin Kavramsal Anlama Testi 4. Sorusuna Yaptıkları Açılamalar İçin Oluşturulan Cevap Kategorilerinin Frekans ve Yüzdeleri

\begin{tabular}{|c|c|c|c|c|c|}
\hline Düzey & Kategoriler(N=33) & \multicolumn{2}{|c|}{ Ön Test } & \multicolumn{2}{|c|}{ Son test } \\
\hline \multirow[b]{2}{*}{ TA } & & $\mathrm{f}$ & $\%$ & $\mathrm{f}$ & $\%$ \\
\hline & $\begin{array}{l}\text { Işık ışınları pürüzsüz yüzeylerde düzgün yansıma yapar. Düzgün } \\
\text { yansıyan ışı ışınları gözümüze daha çok gelir. Bu da arabayı parlak } \\
\text { görmemizi sağlar. Kirli araba ise pürüzlü yüzeye sahip olduğu için } \\
\text { dağınık yansıma yapar. Arabada kendimizi göremeyiz. }\end{array}$ & 4 & 12,12 & 21 & 63,64 \\
\hline KA & Işık ışınları parlak arabadan daha çok yansır. & 5 & 15,15 & 8 & 24,24 \\
\hline AK & Kirli arabada pürüz çok olduğu için pek yansıma olamaz. & 18 & 54,55 & 3 & 9,09 \\
\hline \multirow{2}{*}{ AN } & Açıklama yok & 3 & 9,09 & 1 & 3,03 \\
\hline & Alakasız cevap & 3 & 9,09 & - & - \\
\hline Toplam & & 33 & 100 & 33 & 100 \\
\hline
\end{tabular}

Tablo 19 incelendiğinde ön testte öğrencilerin \%15,15'i kısmi anlama(KA), \%54,55'i alternatif kavram (AK), \%18,18'i anlamama (AN) kategorilerine giren cevaplar verirken, $\% 12,12$ 'si tam anlama (TA) kategorisinde cevap vermişlerdir. Son testte, öğrencilerin \%63,64'ünün tam anlama, \%24,24'ünün kısmi anlama, \%9,09'unun alternatif kavram ve \%3,03'ünün anlamama kategorilerine giren cevaplar verdiği tespit edilmiştir

Kontrol grubu öğrencilerinin IKKAT'ın dördüncü sorusu için yaptıkları açıklamalardan oluşturulan cevap kategorilerinin ön test ve son testteki frekans ve yüzdeleri Tablo 20'de gösterilmiştir.

Tablo 20. Kontrol Grubu Öğrencilerinin Kavramsal Anlama Testi 4. Sorusuna Yaptıklarn Açılamalar İçin Oluşturulan Cevap Kategorilerinin Frekans ve Yüzdeleri

\begin{tabular}{|c|c|c|c|c|c|}
\hline Düzey & Kategoriler(N=31) & Ön & & Son & \\
\hline \multirow[b]{2}{*}{ TA } & \multirow{2}{*}{$\begin{array}{l}\text { Pürüzsüz yüzeylerden yansıyan ışınlar düzgün, pürüzlü } \\
\text { yüzeyler ise dağınık yansıma yapar. Yıanmış araba düzgün } \\
\text { yansıma yapar. Kirli arabanın yüzeyi ise pürüzlüdür. Işığı } \\
\text { dağınık yansıtır. }\end{array}$} & $\mathrm{f}$ & $\%$ & $\mathrm{f}$ & $\%$ \\
\hline & & 2 & 6,45 & 14 & 45,16 \\
\hline KA &  & 5 & 16,12 & 12 & 38,71 \\
\hline $\mathrm{AK}$ & $\begin{array}{l}\text { Pürüzlü yüzeyde yansıma sırasında ışığın bir kısmı yüzeyde } \\
\text { kalır. }\end{array}$ & 16 & 51,61 & 3 & 9,67 \\
\hline \multirow{2}{*}{ AN } & Açklama yok & 5 & 16,12 & 2 & 6,45 \\
\hline & Alakasız cevap & 3 & 9,67 & - & - \\
\hline Toplam & & 31 & 100 & 31 & 100 \\
\hline
\end{tabular}

Tablo 20 incelendiğinde ön testte öğrencilerin \%16,12'si kısmi anlama(KA), \%51,61'i alternatif kavram (AK), \%25,81'i anlamama (AN) kategorilerine giren cevaplar verirken, $\% 6,45$ ' $\mathrm{i}$ tam anlama (TA) kategorisinde ce- 
vap vermişlerdir. Son testte, öğrencilerin \%45,16'sının tam anlama, \%38.71'inin kısmi anlama, \%9,67'sinin alternatif kavram ve \%6.45'inin anlamama kategorilerine giren cevaplar verdiği tespit edilmiştir

Tablo 19 ve Tablo 20'deki analiz sonuçları incelendiğinde IKKAT'ın 4. Sorusuna göre OMYM'nin alternatif kavramları gidermede ve tam anlamayı sağlamada $5 \mathrm{E}$ modeline göre daha etkili olduğu görülmüştür.

\section{Tartşma ve Sonuç}

Bu bölümde, araştırma bulgularına dayalı olarak ulaşılan sonuçlar, literatürde yer alan benzer çalışmalarla karşılaştırılarak tartışılmıştır.

$\mathrm{Bu}$ araştırmada, ışık konusunun öğretiminde ortak bilgi yapılandırma modeline göre yapılan öğretimin ve bu süreçte yapılan etkinliklerin altıncı sınıf öğrencilerinin kavramsal anlamalarına etkisi incelenmiştir. Kavramsal anlama testinden (IKKAT') elde edilen bulgular incelendiğinde kontrol ve deney gruplarının ön test puanları için yapılan bağımsız t-testi sonucunda gruplar arasında kavramsal anlama açısından istatistiksel olarak anlamlı bir fark bulunamamıştır( Bkz. Tablo 4). Bu bulgu, uygulama öncesinde çalışmaya katılan öğrencilerin kavramsal anlamalarının aynı düzeyde olduğu şeklinde yorumlanabilir.

Grupların kendi içerisindeki ön test ve son test verileri incelendiğinde, her iki grupta da ön test ve son test puanları arasında anlamlı bir farklılık olduğu görülmektedir. Bu farkın ise, son test lehine olduğu anlaşılmaktadır (Bkz. Tablo 4). Bu durum, hem kontrol hem de deney grubunda yapilan uygulamaların öğrencilerin kavramsal anlamaları üzerinde etkili olduğunu ortaya koymaktadır. Uygulama sonrasinda deney ve kontrol grubuna uygulanan IKKAT'nin son test puanları arasında deney grubu lehine istatistiksel olarak anlamlı bir fark bulunmuştur (Bkz.Tablo 4 ). İki öğrenme modeli karşılaştırıldığında deney grubunda uygulanan OBYM'nin 6. sınıf öğrencilerin kavramsal anlamaları üzerinde etkisinin kontrol grubunda uygulanan 5E'ye göre daha fazla olduğu söylenebilir. Bunun nedeni; OBYM';nin birçok öğrenme kuramının sentezi şeklinde olması ve öğrenci merkezli etkinliklere daha çok yer vermesi olabilir. Modelin her aşamasında öğrenciler aktif kılınmakta, sürekli düşünmeye, tartısmaya, mevcut bilgilerini gözden geçirmeye teşvik edilmektedir. Sonuç olarak 6. sınıf "Işık Konusu" kazanımlarında OBYM modeli ile yapılan öğretimin deney grubu öğrencilerinin kav- 
ramsal anlamalarına olumlu katkı sağladığı, öğrencilerin bilgi içeren kavramları açıklama sayısında artış gözlendiği belirlenmiştir. Kontrol grubunda da 5E modeli ile yapılan öğretimin öğrencilerin kavramsal anlamaları üzerinde etkili olmasında; fen bilimleri ders kitabında yer alan etkinliklerin rolü olduğu düşünülmektedir.

Deney ve kontrol grubu öğrencilerinin kavramsal anlama testi 1., 2.,3., ve 4. Sorusunun açık uçlu kısmına yaptıkları açıklamalar için oluşturulan cevap kategorileri tablolarının sonuçlarına göre

Tablo 7 ve Tablo 8'deki analiz sonuçları incelendiğinde IKKAT'ın 1. Sorusuna göre OBYM'nin alternatif kavramları gidermede ve tam anlamayı sağlamada $5 \mathrm{E}$ ye daha etkili olduğu, Tablo 11 ve Tablo 12'deki analiz sonuçları incelendiğinde IKKAT'ın 2. Sorusuna göre OBYM'nin alternatif kavramları gidermede ve tam anlamayı sağlamada $5 \mathrm{E}$ ye göre daha etkili olduğu, Tablo 15 ve Tablo 16'daki analiz sonuçları incelendiğinde IKKAT'ın 3. Sorusuna göre OBYM'nin alternatif kavramları gidermede ve tam anlamayı sağlamada $5 \mathrm{E}$ ye daha etkili olduğu, Tablo 19 ve Tablo 20 'deki analiz sonuçları incelendiğinde IKKAT'ın 4. Sorusuna göre OBYM'nin alternatif kavramları gidermede ve tam anlamayı sağlamada $5 \mathrm{E}$ modeline göre daha etkili olduğu görülmüştür.

Deney grubunun kontrol grubuna göre daha başarılı olmasında deney grubuna uygulanan kavramsal değişim metinleri ve kavram karikatürlerinin birlikte kullanılması ile açılanabilir. Kavramsal değişim için OBYM öğretim modeli içerisinde en etkili kullanılan kavramsal değişim metinleridir( Bakırcı ve Çalık, 2013; Er Nas ve Çepni 2016). Ayrıca, kavram karikatürlerinin kullanımının alternatif kavramın belirlenmesinde ve kavramsal değişimde etkili olduğu da belirlenmiştir (Atasoy ve Akdeniz, 2009; Demir, Uzoğlu ve Büyükkasap, 2012; Erdoğan ve Cerrah Özsevgeç, 2012).

Literatürde bu araştırma sonuçları ile benzer sonuca ulaşılan çalışmalar vardır. Ebenezer ve diğ. (2010) araştırmalarında, OBYM ile öğretiminin deney grubundaki öğrencilerin "boşaltım sistemi" konusunda kavramsal değişim süreci geçirdiklerini belirlemişlerdir. Wood (2012) araştırmasında, asitler ve bazlar konusunun OBYM öğretim modeline göre öğretimin lise öğrencilerinin kavramsal değişimine olumlu katkı sağladığı sonucuna ulaşmıştır. İyibil (2011) araştırmasında, Ortak Bilgi Yapılandırma Modelinin uygulandığı deney grubunda bu modelin öğrencilerin kavramsal değişimlerini geliştirdiği sonucuna ulaşmıştır. Kaya, Kaya Zorlu, Aydemir, Kara- 
kaya, Kılıc, ve Emre (2012) araştırmalarında, Ortak bilgi yapılandırma modeline göre öğretim gören fen bilgisi öğretmen adaylarının kavramsal değişimlerinin olumlu olduğunu belirtmişlerdir. Vural, Demircioğlu ve Demircioğlu (2012) araştırmalarında, asitler ve bazlar konusunda OBYM öğretim modeline göre geliştirdikleri öğretim etkinliklerinin üstün yetenekli öğrencilerde kavramsal değişim sürecine olumlu katkı sağladığı sonucuna ulaşmışlardır. Kiryak (2013) araştırmasında, 7. sınıf öğrencilerine ortak bilgi yapılandırma modeli'ne göre "Su Kirliliği" konusunun öğretiminin öğrencilerin kavramsal gelişimlerine olumlu katkı sağladığı sonucuna ulaşmıştır. Bakırcı (2014) araştırmasında, ortak bilgi yapılandırma modelinin uygulandığ 16 . Sınıf öğrencilerinde bu modelin kavramsal değişim sürecine olumlu katkı sağladığını belirlemiştir. Bakırcı, Artun ve Şenel (2016) araştırmalarında, ortak bilgi yapılandırma modeline dayalı fen öğretiminin ortaokul yedinci sınıf öğrencilerinin kavramsal anlamalarına etkisini incelemişler deney grubunda uygulanan OBYM ;nin, kontrol grubunda uygulanan 5E öğretim modeline göre yedinci sınıf öğrencilerinin kavramsal anlamaları üzerinde daha fazla etkili olduğu sonucuna ulaşmışlardır. Bakırcı ve Ensari (2018), OBYM ile yapılan öğretimin, öğrencilerin ısı ve sıcaklık konusundaki akademik başarılarının ve kavramsal anlamalarının artırılmasında ısı ve sıcaklık konusundaki alternatif kavramlarının giderilmesinde etkili olduğunu belirlemişlerdir. Uzunkaya ve Güzel(2019) araştırmalarında, OBYM' ye göre yapılan öğretimin ortaokul öğrencilerinin ses konusundaki kavramsal anlamalarına etkisinin olduğunu belirlemişlerdir. Caymaz ve Aydın (2019) araştırmalarında, ortak bilgi yapılandırma modelinin yedinci sınıf öğrencilerinin elektrik enerjisi ünitesine ilişkin kavramsal anlamalarına etkisinin iyi düzeyde olduğunu belirlemişlerdir.

Farklı sinıf düzeyleri ve fen bilimleri dersinin farklı ünitelerinde $\mathrm{OBYM}^{\prime}$ ye göre öğretim yapılarak modelin öğrencilerin kavramsal anlamalarına etkisi araştırılabilir. Böylece modelin kullanılabilirliği ve etkisi hakkında daha fazla bilgi edinilebilir. 
EXTENDED ABSTRACT

\title{
The Effect of Teaching Based on the Common Knowledge Construction Model on the Conceptual Understanding of Sixth Grade Students Regarding the Subject of Light \\ *
}

\author{
Huriye Yıldızbaş - Hatice Güzel \\ Ministry of National Education, Karamanoğlu Mehmet Bey University
}

Understanding of science-related concepts, which are of great importance in our daily life, is very important for students to create knowledge and to realize their permanent learning. Limited subject area knowledge makes it difficult for students' conceptual understanding. Providing students with a conceptual understanding on any subject is among the basic objectives of education (Calik et al., 2007).

Conceptual understanding is the concept development process; it is the disclosure, interpretation, exemplification and classification of information. Realization of conceptual understanding in Science course can be achieved by embodying abstract concepts, using visual materials and including different techniques (Gobert and Clement, 1999).

One of the teaching models which is effective in improving students' conceptual understanding is the Common Knowledge Construction Model (CKCM), developed in accordance with the constructivist learning theory. The Common Knowledge Construction Model (CKCM) was developed in 1998 by Ebenezer and Connor. CKCM consists of four stages including Discovering and Classifying, Constructing and Negotiating, Expanding and Transferring, and Reflecting and Evaluating.

In the first stage of the model, all students' thoughts about the subject are tried to be determined in order to eliminate students' alternative concepts. Alternative concepts that arise at this stage are discussed in the second stage and constructed in the third stage. In the second stage, every student should be given the opportunity to express his / her opinion by discussing and thinking. Especially in the third stage, the alternative concepts that arise during the first stage are tried to be eliminated by using different strategies (e.g. conceptual change texts and concept cartoons etc.) (Bakirci, 2014). 
The aim of the study is to investigate the effect of teaching the "Light" subject from the "Light and Sound" unit in the 6th grade Science course in secondary school in terms of teaching according to CKCM on the conceptual understanding of students. The mixed method, in which quantitative and qualitative research methods are used together, was used in this research. For quantitative data, a semi-experimental pattern with pre-test post-test control group, which is one of the experimental research designs, was used.

"Light Subject Conceptual Understanding Test (LSCUT)" was used to determine the effect of CKCM on conceptual change. LSCUT was prepared to be the first and second parts. The first part of LSCUT is a multiple choice with 3 distracters and a correct answer while the second part is designed to be the open end part containing the reason of the answer given in the first part. Answers given to these open-ended questions were used for the qualitative data. The correct option in the first part of LSCUT is given 1 point and the wrong option is given 0 point. The levels used by Er Nas, Calik and Cepni (2012) were used to calculate the scores that students would get from each question and the total of the test (Bakirci, 2014). Statistical operations were made using the SPSS package programme.

The research lasted for three weeks including 6 hours in the experimental group and 6 hours in the control group. Science lessons were taught according to CKCM in the experimental group, and teaching of the subject of light was carried out with activities supported by CKCM. In the control group on the other hand, lessons were conducted according to the $5 \mathrm{E}$ teaching model in accordance with the 2013 Science Course Curriculum.

According to the research findings, it is seen that there is a significant difference between the pre-test and post-test scores of the experimental and control groups. It can be seen that this difference is in favour of the post-test (See Table 4). This reveals that the practices in both control and experimental groups are effective on students' conceptual understanding. A statistically significant difference was found between the post-test scores of LSCUT applied to the experimental and control groups after the application in favour of the experimental group. When the two learning models are compared, it can be said that the effect of CKCM applied in the experimental group on the conceptual comprehension of the 6th grade students is more than the $5 \mathrm{E}$ model applied in the control group. 
According to the results of the answer categories tables created for the explanation of the conceptual comprehension test 1st, 2nd, 3rd and 4th questions of the experiment and control group students, it can be seen that CKCM is more effective than $5 \mathrm{E}$ in eliminating alternative concepts and providing full understanding. The reason why the experimental group is more successful than the control group may be the use of conceptual change texts and concept cartoons applied to the experimental group together.

\section{Kaynakça / References}

Abraham, M. R., Gryzybowski, E. B., Renner, J. W., ve Marek, A., E. (1992). Understanding and misunderstanding of eighth graders of five chemistry concepts found in textbooks. Journal of Research in Science Teaching, 29(2), 105-120.

Anderson, C. W. (2007). Perspectives on science learning. S. K. Abell \& N. G. Lederman (Eds.), Handbook of research on science education içinde (s. 3-30). Mahwah, NJ: Erlbaum

Ayas, A.ve Demirbaş, A. (1997). Turkish secondary students" conception of introductory chemistry concepts. Journal of Chemical Education, 74(5), 518-521.

Atasoy, Ş. ve Akdeniz, A. R. (2009, Ekim). Kavram karikatürlerinin etki-tepki kuvvetleri ile ilgili yanılgiları gidermeye etkisi. 3. Uluslararası Bilgisayar ve Öğretim Teknolojileri Sempozyumu, Karadeniz Teknik Üniversitesi, Trabzon

Bakırc, H. ve Çepni, S. (Haziran, 2012). Fen ve teknoloji öğretimi için yeni bir model: Ortak bilgi yapılandırma modeli. Sözlü bildiri, X. Ulusal Fen Bilimleri ve Matematik Ĕ̆itimi Kongresi, Niğde Üniversitesi, Niğde.

Bakırcı, H. ve Çepni, S. (2014). Fen bilimleri dersi öğretim programı temelinde ortak bilgi yapılandırma modelinin irdelenmesi. Fen Bilimleri Öğretimi Dergisi, 2(2), 83-94.

Bakırcı, H. ve Çalık, M. (2013). Adaptasyon ve doğal seçilim konusunda geliştirilen rehber materyallerin sekizinci sınıf öğrencilerinin alternatif kavramlarının giderilmesine etkisi. Eğitim ve Bilim Dergisi, 38(168), 215-229.

Bakırc, H. (2014). Ortak bilgi yapılandırma modeline dayal öğretim materyali tasarlama, uygulama ve modelin etkililiğini değerlendirme çalı̧ması: Işık ve Ses Ünitesi Örneği. Doktora Tezi, Karadeniz Teknik Üniversitesi, Eğitim Bilimleri Enstitüsü, Trabzon.

Bakırc, H., Artun, H.ve Şenel, S. (2016). Ortak bilgi yapılandırma modeline dayalı fen öğretiminin ortaokul yedinci sınıf öğrencilerinin kavramsal anlamalarına etkisi: Gök cisimlerini tanıyalım. YYÜ Eğitim Fakültesi Dergisi, 13(1), 514-543. 
Bakırcı, H. ve Ensari, Ö. (2018). Ortak bilgi yapılandırma modelinin 1Sı ve sıcaklık konusunda lise öğrencilerinin akademik başarılarına ve kavramsal anlamalarına etkisi. Eğitim ve Bilim, 43(196), 171-188.

Biernacka, B. (2006). Developing scientific literacy of grade five students: a teacher researcher coolaborative effort. Unpublished Thesis of Doctoral, The University of Manitoba, Kanada

Caymaz, B.ve Aydın, A.(2019). Ortak bilgi yapılandırma modelinin yedinci sınıf öğrencilerinin elektrik enerjisi ünitesine ilişkin kavramsal anlamalarına etkisi. Kastamonu Education Journal, 27(5), 1955-1975.

Cerit Berber, N. ve Sarı M (2009). Kavramsal değişim metinlerinin iş, güç, enerji konusunu anlamaya etkisi. Selçuk Üniversitesi Ahmet Keleşoğu Eğitim Fakültesi Dergisi, 27, 159-172.

Cerit Berber, N.ve Sarı M (2010). Kavramsal değişime dayalı öğretim stratejilerinin fizik dersine yönelik bazı duyuşsal özelliklerin gelişimine etkisi. Ahi Evran Üniversitesi Kırşehir Ĕ̆itim Fakültesi Dergisi, 11(2), 45-64.

Creswell, J. W. ve Plano Clark, V. L. (2007). Designing and conducting mixed methods research (1. Baskı). London: Sage Publications Ltd.

Çepniİ, S. (2014). Araştırma ve Proje Çalışmalarına Giriş. Trabzon: Celepler Matbaacılık ÇepniI, S., Ayvacı, H. Ş. ve Bakırcı, H. (2015). Ortak Bilgi Yapılandırma Modeli Hakkında Fen Bilimleri Öğretmenlerinin Görüşleri. YYÜ Eğitim Fakültesi Dergisi, 11, 97-127.

Çepni, S., Özmen, H. ve Bakırcı, H. (Haziran, 2012). Ortak bilgi yapılandırma modeline uygun öğretim materyali geliştirilmesi: Işığın madde ile etkileşimi ve yansıma örneği, Sözlü bildiri, X. Ulusal Fen Bilimleri ve Matematik Eğitimi Kongresi, Niğde Üniversitesi, Niğde.

Ebenezer, J. V. ve Cannor, S. (1998). Learning to teach science: A model for the 21 century. Upper Saddle River, New Jersey: Prentice-Hall, Inc., Simon and Schuster/A. Viacom Company

Ebenezer, J., Chacko, S. ve Immanuel, N. (2004). Common knowledge construction model for teaching and learning science: application in the indian context. An international conference to review research on science, technology and mathematics education, Proceedings of International Centre (pp.25-27). Dona Paula, Goa, India.

Ebenezer, J., Chacko, S., Kaya, O. N., Koya, S. K. ve Ebenezer, D. L. (2010). The effects of common knowledge construction model sequence of lessons on science achievement and relational conceptual change. Journal of Research in Science Teaching, 47(1), $25-46$. 
Erdoğan, A. ve Cerrah Özsevgeç, L. (2012). Kavram karikatürlerinin öğrencilerin kavram yanılgilarının giderilmesi üzerindeki etkisi: Sera etkisi ve küresel 1sınma örneği. Türk Fen Eğitimi Dergisi, 1(2), 1-13.

Er Nas, S. ve Çepni, S. (2016). Rehber materyallerin öğrencilerin kavramsal anlamaları üzerine etkisi: "Isının yayılma yolları" örneği. Marmara Üniversitesi Atatürk Ĕ̆itim Fakültesi Eğitim Bilimleri Dergisi, (43):135-155.

Demir, Y., Uzoğlu, M. ve Büyükkasap, E. (2012). Fen bilgisi öğretmen adaylarının kuvvet ve hareket ile ilgili sahip olduğu kavram yanılgilarının belirlenmesinde kullanılan karikatürlerin ve çoktan seçmeli soruların etkililiğinin karşılaştırılması. Ĕ̆itim ve Öğretim Araştırmaları Dergisi, 1(1), 88-102.

Gobert, J. D. ve Clement, J. J. (1999). Effects of student-generated diagrams versus student-generated summaries on conceptual understanding of causal and dynamic knowledge in plate

Hyslop-Margison, E. J.ve Strobel, J. (2007). Constructivism and education: Misunderstandings and pedagogical implications. The Teacher Educator, 43(1), 72-86,

Güzel, H. ve Yıldızbaş, H. (2017). Ortak bilgi yapılandırma modeline dayalı öğretimin öğrencilerin eleştirel düşünme becerilerine etkisi. 1. Uluslararası Sosyal Bilimler ve Eğitim Araştırmaları Sempozyumu, Bildiri Kitabı, 406-413, 3-5 Kasım, Antalya, Türkiye

İyibil, Ü. (2011). A new approach for teaching 'energy' concept: The common knowledge construction model. Western Anatolia Journal of Educational Sciences (WAJES), Dokuz Eylül University Institute ,1-8.

Kaya, O. N., Kaya, Z., Zorlu, M., Aydemir, S., Karakaya, D., Kılıc, A. ve Emre, İ. (2012). Fen ve teknoloji öğretmen adaylarmm ortak bilgi inşa modeli ve uygulamalarn ile ilgili görüşleri. Uygulamalı Eğitim Kongresi. Orta Doğu Teknik Üniversitesi, Ankara.

Karsll, F.ve Ayas, A. (2013). Prospective science teachers" alternative conceptions about the chemistry issues. Necatibey Faculty of Education Electronic Journal of Science and Mathematics Education, 7(2), 284-313.

Kayalı, H. A.ve Tarhan, L. (2004). İyonik bağlar konusunda kavram yanilgilarinin giderilmesi amacıyla yapılandırmacı aktif öğrenmeye dayalı bir rehber materyal uygulaması. Hacettepe Üniversitesi Ĕ̆itim Fakültesi Dergisi, 27, 145-154.

Kiryak, Z. (2013). Ortak bilgi yapılandırma modelinin 7. sinı öğrencilerinin su kirliliği konusundaki kavramsal anlamalarna etkisi. Yayınlanmamış yüksek lisans tezi, Karadeniz Teknik Üniversitesi, Trabzon 
Mutlu, A.,ve Acar Şeşen, B. (2016). Evaluating of preservice science teachers"e understanding of general chemistry concepts by using two tier diagnostic test. Journal of Baltic Science Education, 15(1), 79-96.

Milli Eğitim Bakanlığ[MEB], (2018). Fen bilimleri dersi öğretim programı (İlkokul ve ortaokul 3, 4, 5, 6, 7 ve 8. smiflar). Ankara: T. C. Milli Eğitim Bakanlığı,

Orgill, M.ve Bodner, G. (2004). What research tells us about using analogies to teach chemistry. Chemistry Education Research and Practice in Europe, 5(1), 15-32.

Öztunç, M. 1999. Yaratıcı düşünce üzerinde ailenin etkisi. Sakarya Üniversitesi, Sosyal Bilimler Enstitüsü, Yüksek Lisans Tezi, Sakarya.

Reid, N. (2008). A scientific approach to the teaching of chemistry. What do we know about how students learn in the sciences, and how can we make our teaching match this to maximise performance? Chemistry Education Research and Practice, 9(1), 51-59.

Sinan O. (2007). Fen bilgisi ögretmen adaylarmm proteinler ve protein sentezi ile ilgili kavramsal anlamaları. Yayınlanmamış doktora tezi, Fen Bilimleri Enstitüsü, Balıkesir Üniversitesi, Balıkesir.

Treagust, D. F. ve Duit, R. (2008). Conceptual change: a discussion of theoretical, methodological and practical challenges for science education. Cultural Studies of Science Education, 3(2), 297-327.

Uzunkaya, M. ve Güzel, H, (2019). Ortak bilgi yapılandırma modeline dayalı fen öğretiminin öğrencilerin başarılarına, eleştitel düşünme becerilerin kavramsalanlamalarına etkisi. Journal of Social and Humanities Sciences Research (JSHSR), 6(42), 2656-2667.

Vural, S., Demircioğlu, H. ve Demircioğlu, G. (2012, Mayıs). Genel bilgi yapilandırma modeline uygun geliştirilen bir öğretim materyalinin üstün yetenekli ögrencilerin asit-baz kavramlarmı anlamaları üzerine etkisi. IV. Uluslararası Türkiye Eğitim Araştırmaları Kongresi.

Yıldızbaş, H. (2017). Ortak bilgi yapılandırma modeline dayah öğretimin öğrencilerin akademik başarlarna ve eleştirel düşünme becerilerine etkisi. Yüksek Lisans Tezi, Necmettin Erbakan Üniversitesi, Eğitim Bilimleri Enstitüsü, Konya

Wood, L. C. (2012). Conceptual change and science achievement related to a lesson sequence on acids and bases among African American alternative high school students: A teacher's practical arguments and the voice of the "other. Unpublished doctoral dissertation, Wayne State University. 


\section{Kaynakça Bilgisi / Citation Information}

Yıldızbaş, H. ve Güzel, H. (2020). Ortak bilgi yapılandırma modeline göre yapılanÖğretimin altıncı sınıf öğrencilerinin ışık konusu-na ilişkin kavramsal anlamalarına etkisi. OPUS-Uluslararası Toplum Araştırmaları Dergisi, 16(29), 1718-1750. DOI: 10.26466/opus.751220 